\title{
The grey vote: Determinants of older voters' party choice in Britain and West Germany ${ }^{\text {is }}$
}

\author{
Achim Goerres*
}

Max Planck Institute for the Study of Societies, Paulstrasse 3, 50676 Cologne, Germany

\begin{abstract}
To what extent do older people vote differently from younger people? This article tests two generational and two life-cycle hypotheses with British and West German data. First, older voters belong to a political generation whose party preferences are shaped by the party fortunes experienced in early elections. The more de-aligned the party system, however, the less strong and clear generational differences seem to become. Second, New Politics parties are less favoured among older generations. Third, there is no evidence that ageing voters prefer to cast their ballots for economically more conservative parties. Finally, in more proportional electoral systems, older people seem to have a preference for larger parties that can leave repeated impressions on them as they age. (c) 2007 Elsevier Ltd. All rights reserved.
\end{abstract}

Keywords: Older voters; Grey vote; Political generations; Conservatism; Britain; Germany

Many advanced industrial democracies are ageing. Therefore, the group of older voters, who are usually very likely to vote, is growing in relative and absolute terms. Through their high voter turnout and demographic weight, older voters can have a fundamental impact on electoral results. As a consequence, the topic of the 'grey vote' received a great deal of media attention during recent British and German election campaigns, for example.

\footnotetext{
it The British Election Studies are available from the UK Data Archive at Essex University. The Politbarometer and German election studies can be obtained from the Zentralarchiv für Empirische Sozialforschung Cologne. The coded data sets can be downloaded from my home page. The author would like to thank Michael Bruter, Simon Hix, David Sanders, Jan van Deth, John Sidel and the ES reviewers.

* Tel.: +49 (0) 2212767 160; fax: +49 (0) 2212767555.

E-mail address: goerres@mpifg.de
}

This article seeks to answer the following question: to what extent are older voters different from younger ones with regard to their party choice? If you randomly meet two voters in the street, one who is 70 years old and another who is 30 years old, you may view their age differences from two perspectives. On the one hand, they belong to different generations that do not share political preferences because of their differing socialisation experiences. On the other hand, the two are at different stages in their life cycles, a factor that influences their political interests.

Depending on which perspective is more dominant, the electoral outcome in an ageing democracy will be fundamentally different. Generational variations only have an impact until the voters of that particular generation die. If generational effects explain the differences between the grey vote and others, the demographic process of ageing will not have much of a permanent effect 
because one older generation will be different from the next. The grey vote in one election will vote differently from the grey vote in another election. In contrast, lifecycle differences are stable across generations. They are driven by sociological and psychological forces that make different generations become more similar to each other as they age. If life-cycle effects are dominant, the voting outcome for an ageing democracy due to the large voting impact of older voters - will be permanently changed. Here, the grey vote constitutes a stable factor in electoral politics. This is the perspective that is assumed by much of the apocalyptic literature about the effects of demographic ageing on politics (see for example, Peterson, 1999).

This article reviews the existing generational and life-cycle hypotheses and tests them by comparing Britain and West Germany. The four major findings of this study suggest that the two perspectives need to be embedded in the overall structures of the party system if we are to interpret their influence correctly. First, the idea can be refuted that people more often vote for economically more conservative parties the older they become. Second, there are indeed growing generational preferences for New Politics parties, like the German Greens. These indicate that the current older cohort is still less likely to vote for such parties. Third, some parties can leave a more prominent impression on ageing electors through repeated government participation or their relatively large and constant electoral size. This effect only seems to exist to some degree in party systems with proportional representation. Finally, political generations matter more when the party system is characterised by weaker de-alignment. Political impressions made in young adulthood are carried through our lives, but even more so if the overall volatility is low, because the strength of generational socialisation is one observable implication of the state of de-alignment. The combined importance of life-cycle and generational factors that are embedded in the macrofactor of de-alignment and in features of the electoral system shows that the electoral outcomes can be very different in ageing electorates and that neither the life-cycle nor the generational perspectives generally dominate to a degree sufficient to explain older voters' party choice.

Section 1 reviews the most prominent hypotheses about age-related effects on voting behaviour. In Section 2, I present the research design, predictions about differences between political generations, and the data. In Section 3, I first analyse the differences between age groups and political generations across time before I test all hypotheses in various logistic regression models. Section 4 concludes the article.

\section{A review of existing hypotheses}

There are no existing studies that specifically analyse the determinants of older people's voting choice, neither for Germany nor for Britain. There are a few descriptive contributions to research, but no rigorous analyses (Bürklin, 1987; Stadie, 1986; Vincent et al., 2001). Some studies look at the impact of voters' age on their political attitudes or voting behaviour. Compared with younger voters, older voters are evidently at a different stage of their life cycle and also belong to a different generation.

\subsection{Older voters and the life cycle}

The most prominent group of hypotheses from the life-cycle perspective assumes that people grow more conservative with age (Crittenden, 1962; Glenn, 1974). In this context, electoral conservatism is argued to exist generally in two different forms: first, citizens become economically more conservative as they age and vote accordingly because they accumulate more material goods that they want to preserve (Binstock and Quadagno, 2001); second, older people become more authoritarian (Danigelis and Cutler, 1991; Tilley, 2005).

Whereas the early findings of more pro-Republican voting in the 1960s were refuted as cohort effects in the 1970s (Cutler, 1977), more recent empirical studies have used more elaborate statistical techniques to separate cohort and life-cycle effects. They found small tendencies to favour the conservative Tories in Britain or the Christian Democrats in Germany in addition to generational effects (Falter and Gehring, 1998; Gehring, 1994; Rattinger, 1992; Tilley, 2002, 2003).

U.S. evidence that seemed to show growing authoritarianism among older people was reassessed as a cohort effect because the attitudes in the issue domains measuring authoritarianism generally shifted toward the progressive side (Danigelis and Cutler, 1991). Tilley (2005) comes to a similar conclusion looking at British data.

Another life-cycle hypothesis that remains untested can be derived from Barnes (1989). As we age, we develop a stronger bias to vote for parties that are large and/or regularly part of government. As major players in government or the opposition, these parties can repeatedly leave an impression on ageing voters. Consequently, smaller parties are at a disadvantage among older voters because their sustainable legacy in the minds of these voters is less well established. The hypothesised causal chain hinges on the assumption that party identification works differently for larger than for smaller parties. Younger voters should support minor parties disproportionally before they learn which 
parties satisfy them over time (see also Cain and Ferejohn, 1981; Clarke et al., 1979; Himmelweit et al., 1985).

\subsection{Older voters and generations}

Within the school of research that uses party identification as a main predictor of party choice, age plays a double role: it stands for membership in a political generation and for the intensity to which party identification could be built up (which is, strictly speaking, a life-cycle phenomenon). Butler and Stokes (1983 [1974]) have shown that young people are susceptible to the political forces during their impressionable years, i.e. when they first go and vote. The dominance of a party leaves its mark on the youngest cohort of new voters. Over the course of their lives, this impression is strengthened through growing party identification with that party. These voters perceive all upcoming political events through the lenses of their party identification. Thus, in old age, the cohort as a whole can potentially be different from younger cohorts that do not share the socialisation experience and have not had the time to build up allegiances (see also Campbell et al., 1960; Cassel, 1999; Claggett, 1981; Converse, 1969, 1976; Glenn and Hefner, 1972; Gluchowski, 1983; Markus, 1983; Niemi et al., 1985; Tilley, 2002). For example, Miller and Shanks (1996) demonstrate the pro-Democratic tendency among members of the American New Deal generation who were young in the early 1930s. Social scientists term a cohort that shares political socialisation experiences a 'political generation', following an essay by Mannheim (1997 [1928]).

Another generational hypothesis demands that older cohorts are less inclined to vote for New Politics parties, like the Green parties, because these parties represent post-materialist values that are less common among generations born before World War II (Inglehart, 1990).

\subsection{A critique of the existing studies}

Our understanding of why older people vote differently from younger people can be significantly improved in two ways. First, all these hypotheses should be tested in conjunction. The life-cycle and generational perspectives are compatible with each other. Older people can vote differently because they belong to a different generation and because they are at a different stage in their life cycle. For example, a British voter might belong to the political generation that first voted in 1945 and was subsequently much more pro-Labour than earlier or later cohorts because it experienced the introduction of the
Labour welfare state reforms. As that cohort ages, its members could become more conservative, so that an increasing number switch to the Tories or the Liberals. Compared with other political generations, however, the likelihood that these people will vote for the Conservatives will still be lower. Since both perspectives can be true, we still need to ask which perspective has the greater explanatory power and whether the balance between the two is affected by structural factors.

Second, the potential influence of structural factors stemming from the party system makes it necessary to conduct empirical tests from a comparative perspective and to use more than one country. What all other empirical studies lack are the implications of cohort or lifecycle effects in international comparisons. If voters retain an electoral 'imprint' of their political socialisation at young adulthood, this experience will be defined by national circumstances of the time. Another country has a different constellation of parties and candidates that shapes the socialisation experience of the same cohort differently than in the first country. Furthermore, if voters become, for example, more biased toward larger parties because of a public sphere that is skewed in favour of successful parties, this effect should be similar across countries as the theoretical reasoning lies in cognitive processes and not the nature of the national electoral process.

Also, the presented hypotheses deal with different characteristics of parties: their past, ideology, or size in the public sphere. If only one country is analysed, these effects are very likely to be confounded in a limited number of parties. Comparing several countries eases the problem because the number of constellations is increased.

Table 1 summarises the various hypotheses from the literature and spells out the testable implications for West Germany and Britain. I will not test the hypotheses about authoritarianism as it has recently been refuted (Danigelis and Cutler, 1991; Tilley, 2005).

\section{Testing the hypotheses in Britain and West Germany}

\subsection{Research design}

Testing life-cycle and generational effects means looking at longitudinal data, in this case accumulated cross-sectional surveys. At any given point in time, the voting behaviour of an age group can be influenced by a mixture of cohort and life-cycle determinants. For instance, the voting results of the $60+$ age group in the 1997 British General Election could be due to factors that only influence people who are 60 and older or due 
Table 1

Overview of hypotheses

\begin{tabular}{|c|c|c|}
\hline Title of hypothesis & Summary & Testable implications for Britain and West Germany \\
\hline \multicolumn{3}{|l|}{ Life-cycle hypotheses } \\
\hline $\begin{array}{l}\text { Growing economic } \\
\text { conservatism }\end{array}$ & $\begin{array}{l}\text { Older people vote economically more } \\
\text { conservative because they have more to preserve. }\end{array}$ & $\begin{array}{l}\text { The most conservative parties economically (FDP, Tories) } \\
\text { should have an advantage among older people. } \\
\text { The most progressive parties economically (SPD, Labour) } \\
\text { should be at a disadvantage among older voters. }\end{array}$ \\
\hline Larger-party advantage & $\begin{array}{l}\text { Over their lifetimes, voters collect impressions } \\
\text { of parties and tend to favour known parties. } \\
\text { Larger parties or smaller parties in government } \\
\text { are more likely to leave such impressions. }\end{array}$ & $\begin{array}{l}\text { Parties that have a history of strong electoral showing or } \\
\text { government participation (CDU/CSU, SPD, FDP or Tories, } \\
\text { Labour) should have an advantage among older people. }\end{array}$ \\
\hline \multicolumn{3}{|l|}{ Generational hypotheses } \\
\hline Political generation & $\begin{array}{l}\text { A cohort is influenced by electoral events and } \\
\text { fortunes at the time when its members come } \\
\text { of age politically. }\end{array}$ & $\begin{array}{l}\text { Historically defined political generations should show } \\
\text { differences vis-à-vis each other in electoral preferences. }\end{array}$ \\
\hline New Politics & $\begin{array}{l}\text { More recent generations favour parties that have } \\
\text { an emphasis on post-materialist values. }\end{array}$ & $\begin{array}{l}\text { Older cohorts in West Germany should be less likely } \\
\text { to vote for the Green Party. }\end{array}$ \\
\hline
\end{tabular}

to factors that only have an impact on those born in 1937 and earlier or due to a combination of these factors. Therefore, it is necessary to follow cohorts through time. If the group that was 60-69 in 1997 had voted along similar lines in 1987, this might be an indication that the cohort influence prevailed over the ageing effect.

There remains the problem that a life-cycle effect can be a combination of period effects influencing only that particular cohort. This is where another advantage of analysing two countries becomes evident. It is a safe assumption that a cohort in one country is subject to fundamentally different electoral experiences than the same cohort in another country and that period effects are different as well. Even if these cohorts share common experiences or events, such as the 1968 student revolution, the transmission process toward individual socialisation depends on the national party system of the time. The 1968 student revolution in West Germany coincided with the beginning of a new era of social democratic reign, so that the young people of the time saw the Social Democratic Party (SPD) as one that was different from the Christian Democrats (CDU/CSU) who had been in power for 20 years. In Britain the situation was different for Labour was in power at the time and had taken turns at shouldering governmental responsibility with the Conservatives since 1945 . For young British people at the time, Labour was as much a part of the establishment as were the Tories. In sum therefore, similar findings of life-cycle effects in two countries confirm their nature as life cycle rather than interaction effects between period and cohort.

I selected West Germany and Britain as the two country backgrounds against which to test the hypotheses for four reasons. First, practicality played a role because both countries have a long tradition of high-quality surveys that can be used in a pooled analysis. Second, the two-party systems are very dissimilar with regard to changes over time. Since 1945, Britain has had a party system that is dominated by two major parties that regularly alternate running a single-party government, the Conservatives and Labour (Norris, 1997). Whereas the patterns of government formation have remained relatively stable since World War II, there have been two major changes. One is the increase of the voting share of the Liberals/Social Democratic Party/Liberal Democrats (henceforth the Liberals) since the 1970s; the other is the emergence of regionalist parties from Scotland and Wales. ${ }^{1}$ West Germany was a two and a half party system for three decades, in which two ideological blocs (the Social Democrats and the Christian Democrats) and one pivotal party, the liberal FDP, dominated voting choice. From the 1980s onwards, the party system changed as the Greens entered the Bundestag. ${ }^{2}$

Third, the main sociological dimensions of party competition are different. British party competition is dominated by a single dimension, namely the socioeconomic one, since class is the only salient political cleavage between the major political parties. There are two dimensions in German national politics. One is the classic left-versus-right socioeconomic dimension. The second dimension is religion, in which one pole can be termed secular and the other religious (Siaroff, 2000, 17).

\footnotetext{
${ }^{1}$ Northern Ireland is excluded from the analysis because of its different party system.

2 The post-communist Socialists (PDS, Linke) did not play a role in the West German party system between 1977 and 2002.
} 
Political parties can be ordered in one- or twodimensional spaces. However, over time, they can shift their ideological stance. These shifts can sometimes be so radical that one party overtakes another within a given dimension. In Britain, the Tories were always more conservative than Labour. Therefore, given a choice of these two parties, the Conservatives were always the more conservative option. The Liberals shifted their relative position on the left-right continuum over the years. This is due to their decline, the fusion with the Social Democratic Party (SDP) and the re-positioning of the Liberals over the last 50 years. In the 1950 s, the Liberals were to the right of the Conservatives, in the 1960s and since 1997 they have been to the left of Labour (Budge, 1999, 5).

In West Germany, the picture is more complicated because of its two-dimensional nature. Socioeconomically, the FDP is the most conservative party, followed by the Christian Democrats, the SPD, and finally since the 1980s - the Greens. On the religion scale, the CDU/CSU is located closer to the religious endpoint of the axis whereas the others are secular parties (Siaroff, 2000, 17).

Finally, de-alignment, the process through which social characteristics lose their traditional explanatory power for voting, affected both countries differently. Britain is thought to be more advanced than West Germany and to have started earlier with the de-alignment process (Franklin, 1992). The question of de-alignment is crucially important in the study of generational effects. If de-alignment takes place, socialisation effects during youth should become less important because social characteristics and early electoral experiences wane in importance. Instead, voting behaviour is increasingly influenced by candidate evaluation and issue positions.

The dissimilarities between the two-party systems allow us to explore the potential impact of macrofactors. I will argue that differences matter when it comes to electoral history (de-alignment and the development of the Green party) and electoral systems, if we are to understand the differences between younger and older voters. In contrast, the dimensionality of the party systems does not play a role.

\subsection{Predictions about political generations}

In order to separate political-generational effects from other age-related effects that are hypothesised to have an impact on older voters' choices, we need theoretically based predictions about the specific sequence of political generations in the two countries. Unfortunately, we cannot learn much from the literature on political generations about the factors that determine their emergence.
We somehow know that generational differences exist. We are not sure, however, how to recognise when a new political generation evolves, why it evolves, and where the next generation starts (Braungart and Braungart, 1986). In addition, generations can be different, depending on the dimension in question; in other words, political, economic or social generations will not necessarily coincide (for a critical review, see Spitzer, 1973).

Nevertheless, there is some evidence that we can discern distinct political generations in terms of political behaviour in West Germany and in Britain. We need to look at historical, electoral developments to hypothesise about the existence of political generations. The critical stage is the electoral context of the time when voters first went to the polls. This has already been suggested by Tilley (2002) with regard to party identification in Britain.

Table 2 shows the assumed political generations for Britain. Butler and Stokes (1983 [1974]) established the existence of the first four generations, and Russell et al. (1992) demonstrated the distinct political preferences of the young generation under Thatcher, which they called 'Thatcher's Children'. The other generations fill the gaps in between, and I have given historical explanations why they should be different. For instance, the generation that first went to the polls in 1945 and 1950 experienced the Labour landslide of 1945, the first Labour-led government, and the establishment of the post-war welfare state. This historical experience should make this cohort, as a whole, more pro-Labour than the previous cohort that first voted in an era of Conservative dominance. I have made predictions for each generation and party, relative to the preceding generation. ${ }^{3}$

Table 3 summarises the assumed political generations for West Germany. ${ }^{4}$ For instance, the largest political generation is the Adenauer Generation. Its

\footnotetext{
${ }^{3}$ With respect to party identification, Tilley (2002) has shown the existence of political generations according to party dominance at the time of socialisation. Clarke et al. (2004) demonstrate the way the 'Thatcher generation' and the 'Blair generation' differed from previous cohorts regarding the civic duty to vote. They also identify the 1945 Cohort as the 'post-war' generation, the 1951-1966 Cohort as the 'Macmillan' generation, and the 1966-1979 Cohort as the 'Wilson/Callaghan' generation. Note, however, that my empirical analysis is not an empirical test of this differentiation because (a) I am using the same data and (b) they examine voter turnout.

${ }^{4}$ See Herbert (2003) for the generations Kriegsjugendgeneration (born 1900 until 1910), which corresponds with my Weimar Generation, the skeptische Generation (born 1925 and 1935), which represents the second half of my Adenauer Generation and die $68 \mathrm{er}$ Generation (born 1940-1949), which corresponds roughly with my Brandt Generation. Merkl (1989) also suggests a typology of political generations for German leaders, depending on their historicalpolitical experience during youth.
} 
Table 2

Political generations in post-war Britain

\begin{tabular}{|c|c|c|c|c|c|c|c|}
\hline \multirow{2}{*}{$\begin{array}{l}\text { Name of political } \\
\text { generation }\end{array}$} & \multirow[t]{2}{*}{ Years of birth } & \multirow{2}{*}{$\begin{array}{l}\text { Dates of } \\
\text { first election }\end{array}$} & \multirow[t]{2}{*}{ Distinct historical context during youth } & \multicolumn{4}{|c|}{ Electoral predictions } \\
\hline & & & & Lab & Cons & Lib & Oth \\
\hline Victorian Generation & $\begin{array}{l}1896 \text { and earlier } \\
\text { (men), } 1887 \text { and } \\
\text { earlier (women) }\end{array}$ & Before 1918 & $\begin{array}{l}\text { Limited franchise, two-party system } \\
\text { with Liberals and Conservatives, } \\
\text { First World War }\end{array}$ & Weak & & & $\begin{array}{l}\text { Few votes due } \\
\text { to two-party } \\
\text { system }\end{array}$ \\
\hline Inter-War Cohort & $\begin{array}{l}\text { 1897-1914 (men), } \\
1888-1914 \text { (women) }\end{array}$ & $1918-1935$ & $\begin{array}{l}\text { Conservative dominance, Labour party } \\
\text { on the rise, Liberals on the decline }\end{array}$ & + & + & - & 0 \\
\hline 1945 Cohort & $1915-1929$ & $1945-1950$ & $\begin{array}{l}\text { Great Depression, World War II, } \\
\text { first majority Labour government } \\
\text { after landslide, installation of } \\
\text { modern welfare state }\end{array}$ & + & - & 0 & - \\
\hline 1951-1966 Cohort & $1930-1945$ & $1955-1966$ & $\begin{array}{l}\text { Conservative dominance, second } \\
\text { Labour government under Wilson } \\
\text { with landslide, Liberals close } \\
\text { to oblivion }\end{array}$ & - & + & - & 0 \\
\hline 1966-1979 Cohort & $1946-1956$ & $1970-1974$ & $\begin{array}{l}\text { Alternating governments, strikes, } \\
\text { revival of Conservative values in } \\
\text { society, growing Liberals, } \\
\text { more parties }\end{array}$ & - & - & + & + \\
\hline Thatcher's Children & $1957-1974$ & 1979-1992 & $\begin{array}{l}\text { Conservative era, Thatcher, } \\
\text { reforms of the welfare state }\end{array}$ & + & - & + & 0 \\
\hline Blair's Children & 1975 and younger & $1997-2001$ & $\begin{array}{l}\text { New Labour shifted toward the } \\
\text { centre, Conservatives in disarray, } \\
\text { LibDems gaining, devolution }\end{array}$ & - & 0 & + & + \\
\hline
\end{tabular}

Signs show expected change relative to the preceding generation.

Table 3

Political generations in post-war West Germany

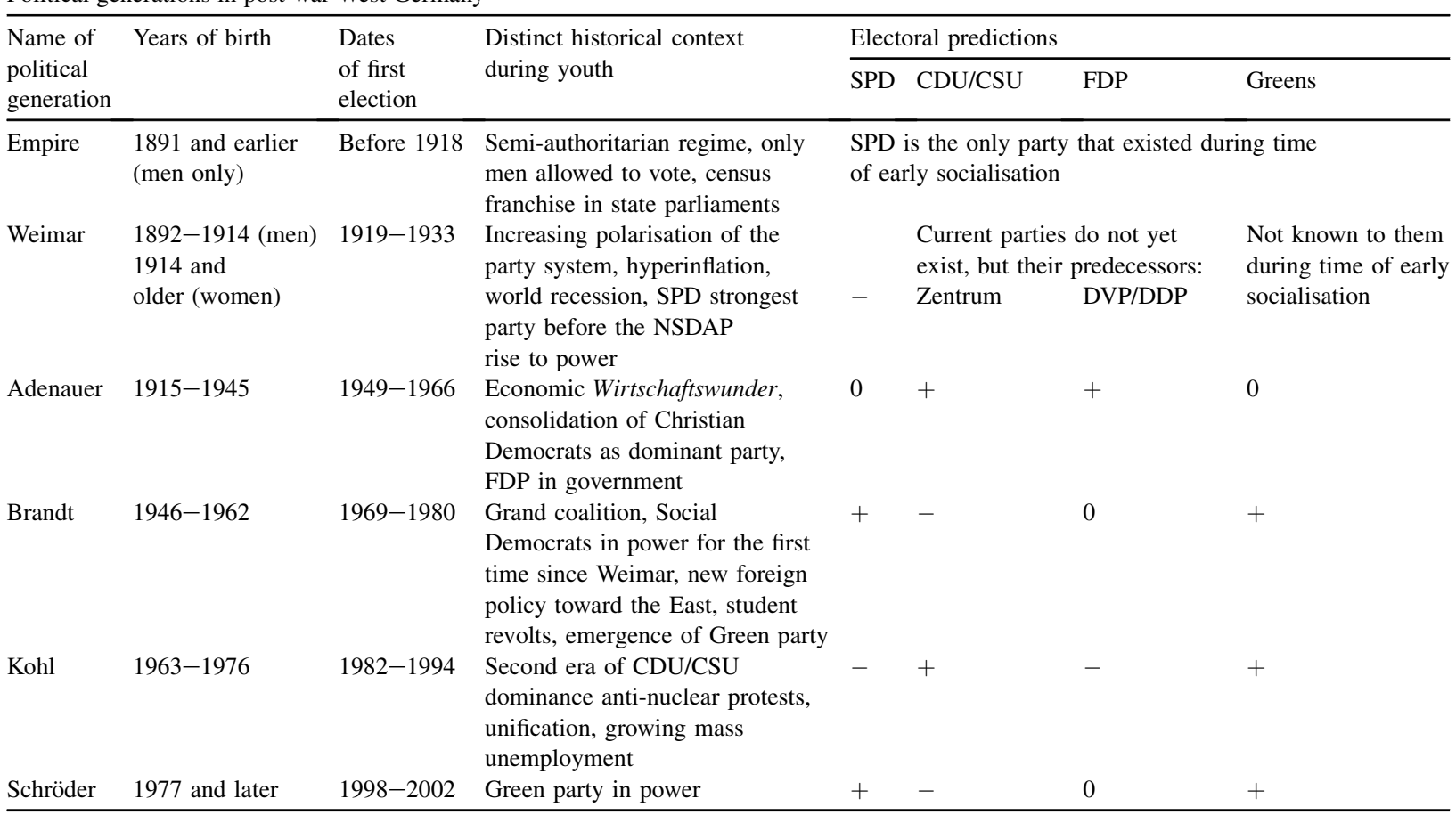

Signs show expected change relative to the preceding generation. 
members first went to free polls in early post-war Germany. It was the era of the Wirtschaftswunder and a strong Christian Democratic party that brought solidity after the political instabilities of the Weimar Republic and the Third Reich. Thus, this generation should be more pro-CDU/CSU than its predecessor, the Weimar Generation. In contrast, the following generation, who first voted between 1969 and 1980, experienced the first post-war SPD-led government, a change in foreign and inner-German policies. Its members should be more pro-SPD than the preceding cohort.

\subsection{The data}

I analyse a multitude of surveys in the empirical part of this article. In the descriptive part, the emphasis is to establish a time series that is as long as possible. For West Germany, I use the whole range of election studies from 1961 until 1998 and Politbarometer poll data for 2002. For Britain, I employ the British Election Studies from 1964 until 2001 and two Gallup surveys from 1958 and 1960. For the regression analysis, I make use of all of the monthly Politbarometer from 1977 until 2002 for West Germany and of the British Election Studies, 1964-2001.

These two data sets differ in some respects. The British Election Studies (1964-2001) are based on face-to-face interviews and cover 11 points in time. The Politbarometer is a monthly telephone survey, similar to the Gallup surveys, which asks respondents how they would vote if there was an election that following weekend. I have divided the British data into two time series, 1964-1979 and 1979-2001. In terms of the predictive power of social class, 1974 can be seen as the first election of a de-aligned era (Clarke et al., 2004), but the number of observations for 1964-1970 alone would make it difficult to estimate the generational effects. The year 1979 and the 1966-1979 Cohort are overlapping baselines, so that we can indirectly compare differences across the divide. In order to allow more comparisons and to minimise the danger of misinterpreting artefacts that might arise from the collinearity structure of the variables, I also report the regressions for the full British sample. ${ }^{5}$

Both data sources have their advantages and limitations. The British data go back into the 1960s, but

\footnotetext{
5 In any pooled cross-sectional time-series analysis, some cohorts (the earliest and the latest) are not followed through their full lifetime. Thus, we cannot compare their behaviour with regard to all possible period-age combinations. The shorter the time period, the bigger this problem becomes.
}

have a rather limited number of observations as far as estimates for individual generations are concerned. Also, it is difficult to include controls in the estimations because some questions have been used differently across time. Nevertheless, I will use five control variables that are to capture the main dimensions of party competition and changes in the social composition of the electorate: gender, age at which education was finished (in groups), council housing (whether the respondent is living in a rented council house or flat), intensity of religious practice (frequency of church attendance) and trade union membership (whether the respondent is a trade union member). ${ }^{6}$ I will not interpret the estimated coefficients since I include these variables only to reduce the noise and compositional effects. The social composition of cohorts has changed over time. Educational levels have risen; religious practice and trade union membership have declined over the decades. Also, women tend to live longer. As a result, the older a cohort becomes, the larger is its proportion of women.

Because the Politbarometer survey was conceptualised from the beginning as a time series, it contains a large number of observations and is easily adapted to include controls: gender, education (highest formal level of education), religious practice (frequency of church attendance) and trade union membership (whether at least one person in the respondent's household is a trade union member). However, this data set only goes back to 1977 . In order to take advantage of the better controls available in the Politbarometer data, I decided not to use the longer German series of election studies in the regression analysis.

\section{Empirical analysis}

\subsection{Descriptive analysis for age groups}

I define older voters to be 60 years and older because 60 approximates the mean retirement age in Britain and West Germany, which can be considered to be an important social division point. Figs. 1 and 2 show the ratio of voters aged 60 and older divided by voters aged 59 and younger from a longitudinal perspective. If the ratio is 1 , it signifies that senior voters do not show a different

\footnotetext{
${ }^{6}$ We must keep a close eye on issues of equivalence. The impact of the university-education factor on party choice, for instance, can hardly be assumed to be the same in the 1960s as it is in the 1990s. Also, some of the questions, e.g. about education, have been changed throughout the years. See Appendix for coding. I do not include social class for Britain because there is no comparable measure for the German data. The education variable, however, should capture the main socioeconomic differences.
} 


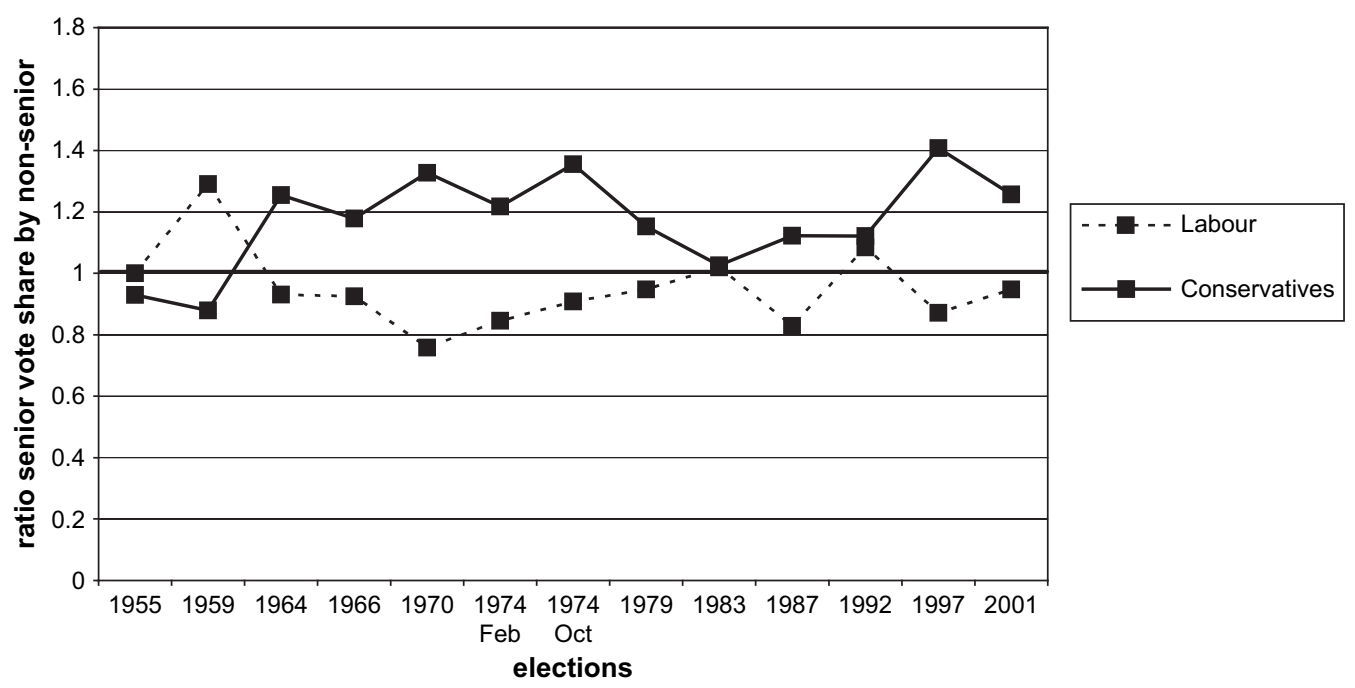

Fig. 1. British party ratios (vote share of voters aged 60 and older divided by those younger than 60) - Conservatives and Labour. Source: own calculation according to British Election Studies, 1964-2001, and Gallup polls 1958 and 1960.

voting pattern. If the ratio is higher than 1 , then older people were more likely to vote for that party than younger people and, vice versa, when the ratio is less than 1 . We can only use observations where respondents indicated for whom they had voted. Non-responses or characteristics of non-voters are not included.

The party ratio of the Conservatives (Fig. 1) is significantly above 1 in 11 out of 13 elections. This means that the Conservatives had an advantage in the group of $60+$ voters in most elections. But the party ratio varies considerably from less than 0.9 to as high as 1.4. The party ratio for Labour seems to mirror the
Conservative age ratio in the opposite direction. It is below 1 in almost all instances where the Conservatives had the edge among older voters. Nonetheless, in two elections $(1959,1992)$ an older voter was more likely to vote for Labour than was a younger voter.

In West Germany (Fig. 2), the Christian Democrats were more likely to be voted for by older voters in all elections. However, the difference between older and younger voters varies between 10\% in 1949 and more than $60 \%$ in 1998. The ratio for the Social Democrats lies below 1 in most, but not all, elections. However, the differences between age groups are much smaller,

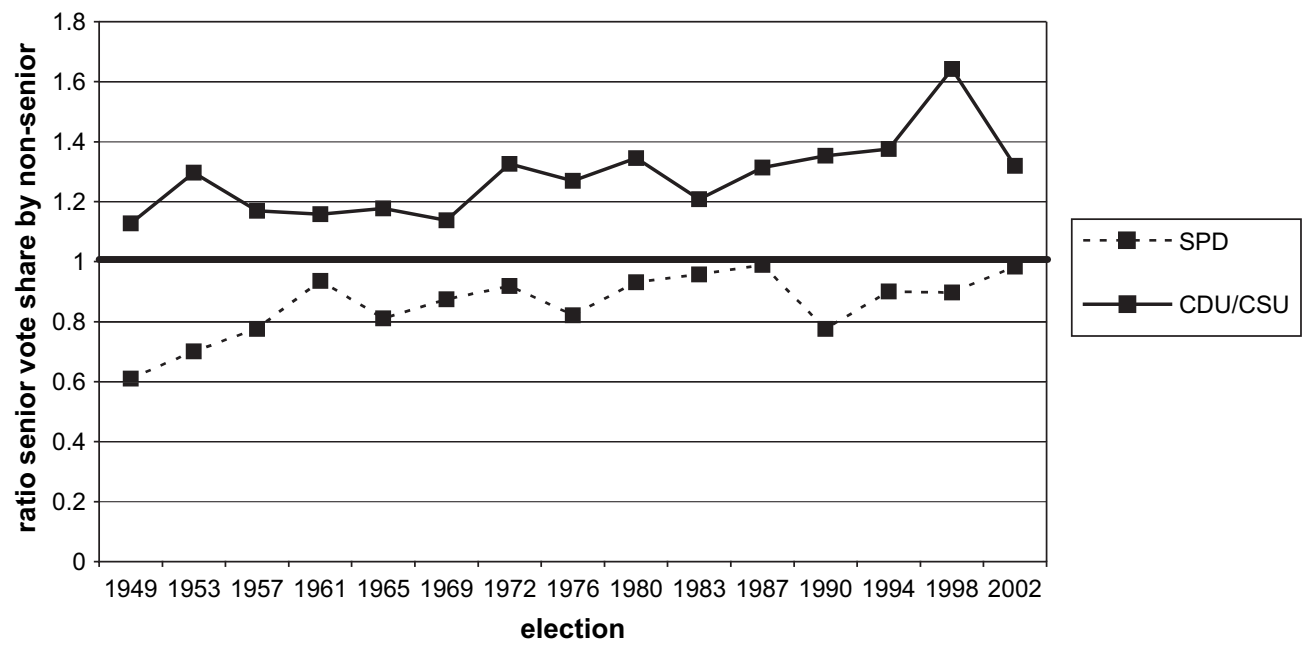

Fig. 2. West German party ratios (vote share of voters aged 60 and older divided by those younger than 60) - CDU/CSU and SPD. Source: own calculation according to German election studies, 1961-1998, and Politbarometer 2002. 
compared with the CDU/CSU. The greatest attraction of younger voters to the SPD was in 1949 with $40 \%$ and the smallest was in 1987 with zero. ${ }^{7}$

At first, these two figures seem to support the hypothesis of increasing conservatism over time. The more conservative party (Tories, CDU/CSU) in each country is generally more favoured among older voters than is the more progressive party (Labour, SPD). However, the strong variation seems to indicate that there are other forces at work as well.

\subsection{Descriptive analysis of political generations}

I will now give a descriptive overview of the patterns of party support of political generations for the social democratic and conservative parties. ${ }^{8}$

The depiction of political generations and the Labour Party is mixed (Fig. 3). Until the mid-1970s, there appears to be a distinct position for each generation: members of the Victorian Generation are least likely to vote Labour, while the 1966-1979 Cohort is most likely to vote Labour. The 1945 Cohort and the 1951-1966 Cohort are in between but do not differ a great deal from each other. From 1979 onward, however, generational differences seem to shrink. The fault line that divides generational voting behaviour into these two general periods might demarcate the consequences of de-alignment through which long-term allegiances (and the two-party system of Labour and Conservatives) ceased to exist.

For the Conservatives (Fig. 4), the pre-1979 period shows clear generational patterns. The Victorian Generation and Inter-War Cohort are most likely to vote Conservative, followed by the 1945 Cohort and 1951-1966 Cohort, which are again too close to each other to represent distinct variations. The 1966-1979 Cohort is least likely to vote Conservative. From 1979 on, the generational differences become relatively small, with the exception of the (then oldest) Inter-War Cohort, which persists to be the strongest pro-Conservative generation.

These generational variations have implications for older voters. In the 1950s, the older voters were largely pro-Conservative (and unlikely to vote Labour). They were members of the Victorian Generation, who first went to the polls during the Liberal-Conservative two-party system. In the 1970s, the majority of older voters were members of the Inter-War Cohort, who first

\footnotetext{
${ }^{7}$ Graphs for the other British and German parties can be obtained from the author.

${ }^{8}$ Graphs and descriptions for the Liberal, Green, and other parties are available upon request.
}

had gone to the polls during Conservative dominance. They, too, were more pro-Conservative (and less likely to vote Labour) than younger voters. In the last elections of the series, older voters who belonged to the Inter-War Cohort were still clearly more pro-Tory. Older voters who belonged to the 1945 Cohort or younger generations show only small differences to other cohorts.

The West German graphs for the Christian and Social Democrats do not show an apparent de-alignment pattern as the British ones do for the Tories and Labour. With the exception of 1983, 1987, and 2002, we can detect some generational differences for the SPD (Fig. 5). The earliest Empire Generation is more likely to vote SPD than its successor, the Weimar Generation, which has the lowest likelihood of all. The Adenauer Generation is again more pro-SPD than the Weimar Generation. Overall, the Brandt Generation is most pro-SPD whereas the Kohl generation is somewhat in between.

Like the conservative Tories, the CDU/CSU shows clearer generational patterns (Fig. 6). The Weimar Generation, most adversarial to the SPD, is most pro-CDU, followed by the Adenauer Generation. The preceding Empire Generation, with the exception of the outlying year 1961 , is up to $30 \%$ less likely to vote CDU/CSU than the Weimar Generation. The difference between the Weimar Generation and the Brandt Generation is as much as $20 \%$. Differences between the Brandt, Kohl, and Schröder generations are not apparent. For older people, we can deduct an interesting picture. Immediately following World War II, older voters as members of the Empire Generation - were less likely to vote CDU and more likely to vote SPD than were middle-aged or younger voters. In the 1970s, older voters from the Weimar Generation were much more likely to vote CDU/CSU than were the young Brandt Generation. Nowadays, older people, as members of the Adenauer Generation, are still more likely to vote for the Christian Democrats and less likely to vote for the SPD.

We have found evidence that some of the hypothesised political generations exist and have also seen that some generations do not seem to be different from adjacent ones. Thus, the differences between younger and older voters do not appear to be stable, but to be the result of the relative contrast among various political generations. Let us now turn to more complex tests.

\subsection{Combined hypotheses-testing in multivariate regressions}

I will first test the existence of the hypothesised generational effects by separating them from any kind of residual age effect. To that end, I will run a series of logistic 

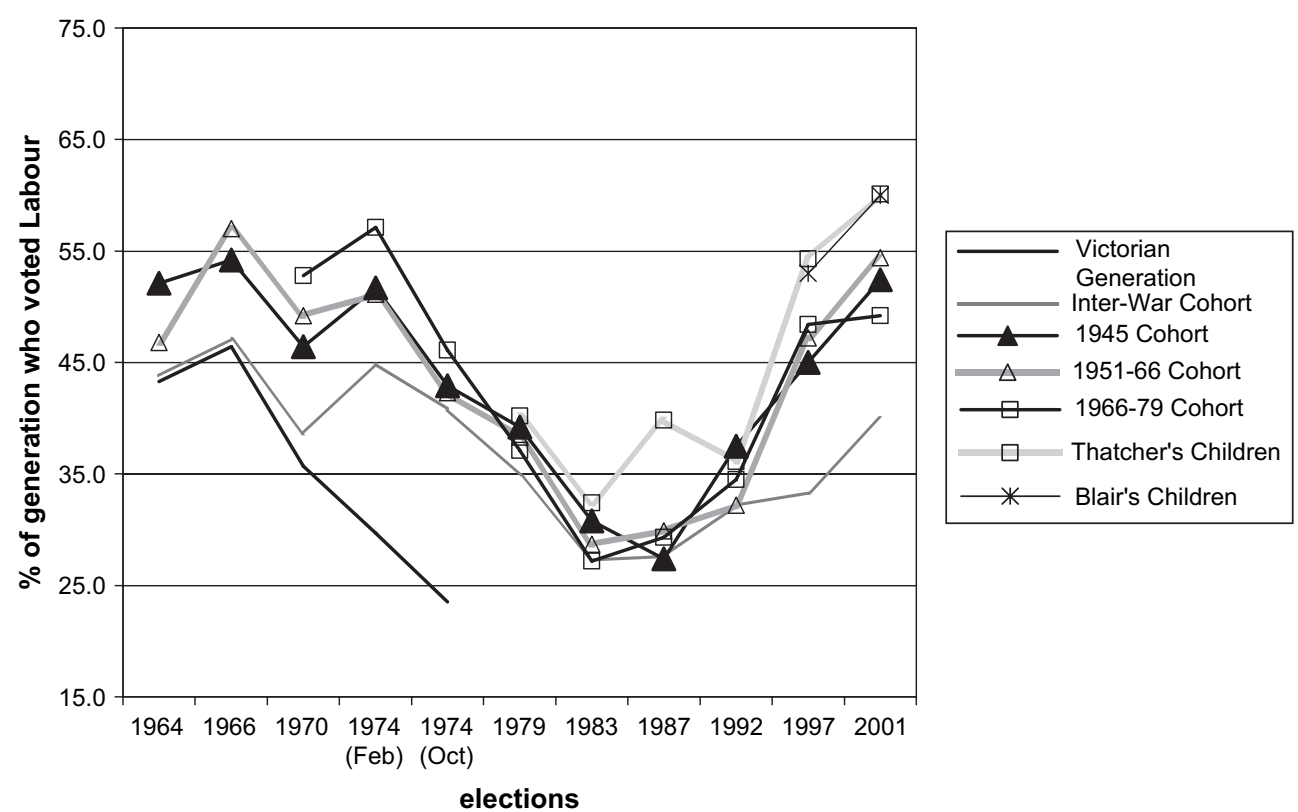

Fig. 3. Proportion of political generations who vote Labour in British elections, 1964-2001. Source: own calculation according to British Election Studies, 1964-2001.
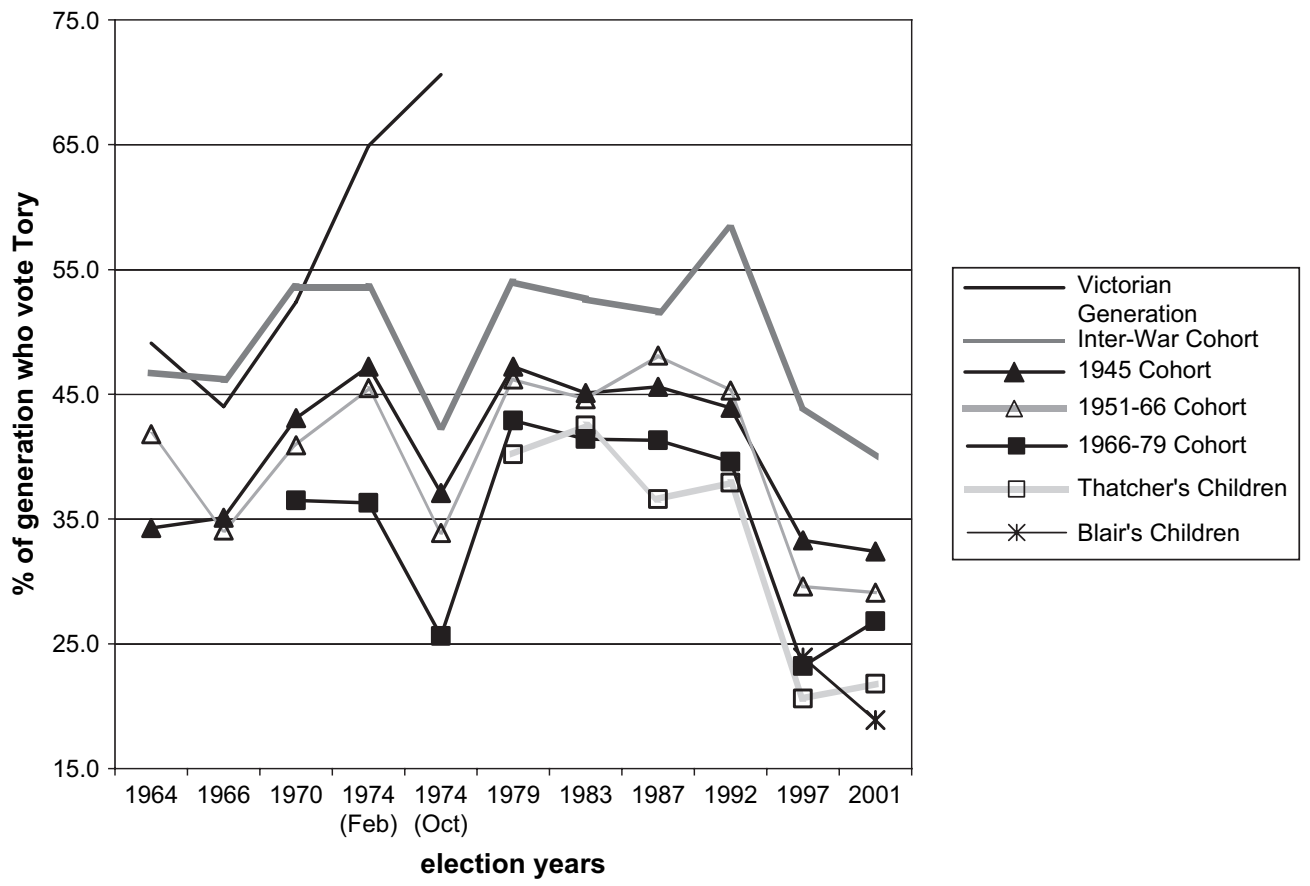

Fig. 4. Proportion of political generations who vote Conservative in British elections, 1964-2001. Source: own calculation according to British Election Studies 1964-2001. 


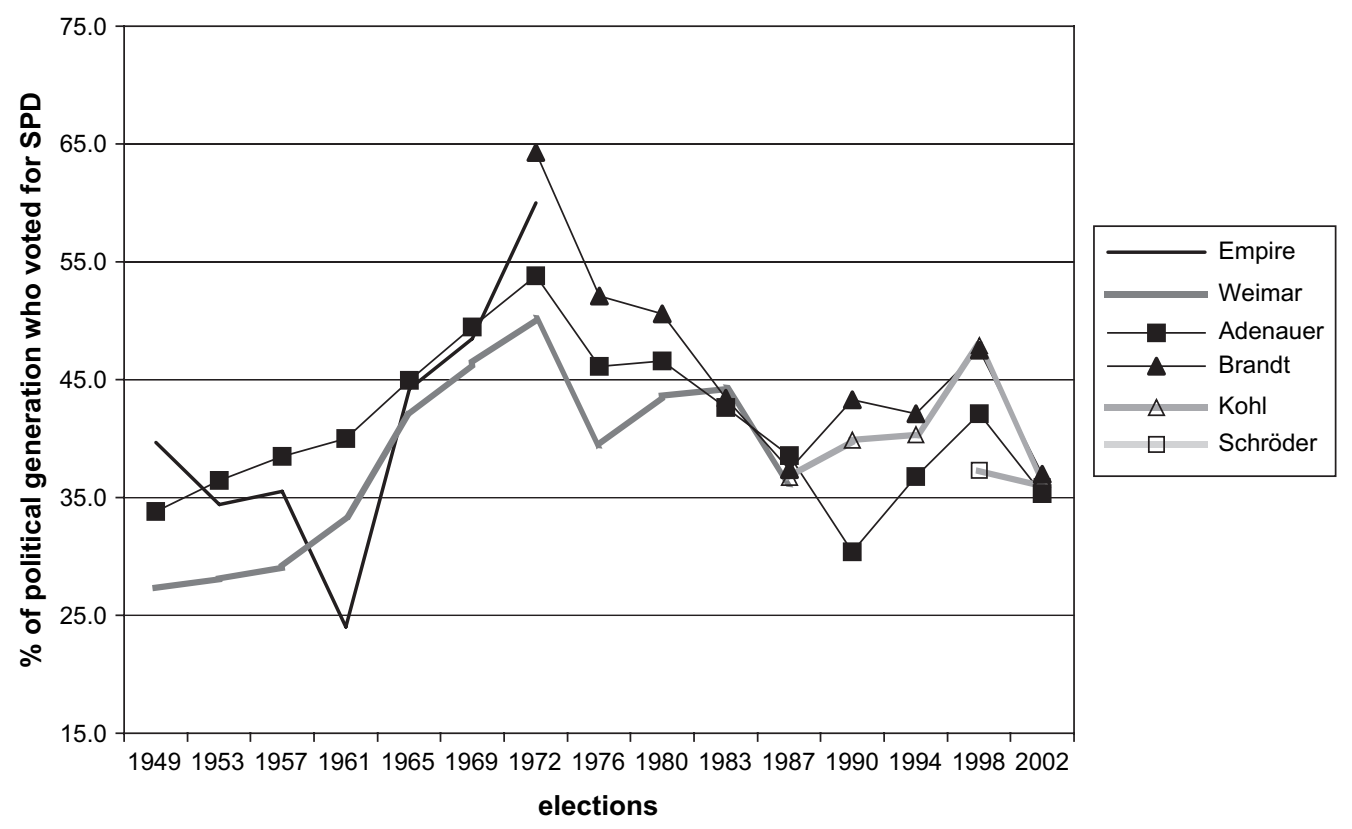

Fig. 5. Proportion of political generations who vote SPD in German elections, 1949-2002. Source: own calculation according to German election studies, 1961-1998, and Politbarometer 2002.

regression models in which the dependent variable is voting for one specific party versus voting for all others. ${ }^{9}$ In addition, I will test the hypothesis about the largerparty advantage by using a different dependent variable, i.e. larger or governmental parties versus smaller parties.

In attempting to estimate the effects of age and generation while controlling for period effects, we easily run into the problem of multicollinearity, i.e. the situation in which independent variables can be predicted to a large degree by other independent variables. If I use year of birth, age, and survey year as predictors, we would have perfect multicollinearity because I can deduct the survey year if I know the respondent's age and year of birth and vice versa, meaning that a strategy against severe collinearity is necessary. The suggested way around this problem is to use dummies for political generations. These generations comprise a decade or more and are of unequal size. The underlying assumption is that the differences in the year of birth within a political generation do not matter. ${ }^{10}$

\footnotetext{
${ }^{9}$ I use logistic rather than multinominal regressions because the predictions that I made for each political generation follows the logic of logistic regression and cannot be tested otherwise.

${ }^{10}$ Overall, multicollinearity does not pose a major problem. In the British regressions, the highest variance inflation factor is 2.8 . In the German regressions, the highest variance inflation factor is 6.8 for the age variable. This latter level of multicollinearity reduces the precision of the estimator. However, due to the large sample size (more than 200,000 observations), this reduction in precision can be tolerated.
}

There are three regressions for each dependent variable in Table 4. The British data are divided into an early period (1964-1979) and a late period (19792001). In addition, there is a regression for the full sample from 1964 to 2001. This threefold division is to test whether de-alignment makes a difference for the results. In the first British period (1964-1979), there are no significant residual variations between age groups that could be captured by the age variable. This lack of significant variation is an important finding. It refutes our conservatism hypotheses for the period 1964-1979. If it had been correct, we would seen that advanced age meant an increase in the tendency to vote for the Tories, the economically most conservative party, and a decrease in the tendency to vote for Labour, the economically most progressive party.

In contrast, there are significant generational variations. Eight out of the 16 relative predictions that we made hold true when we compare the change in point estimates of political generation dummies (see black boxes in Table 5). However, due to sampling error, we cannot always be very sure about this direction of change between generations. The stars in Table 5 indicate where the coefficient of a political generation dummy is significantly different from the coefficient of the preceding generation. Out of the eight correct predictions, only four imply a change that is at least significant at the 0.05 level. These results mean that the noise within generations is still quite large and could 


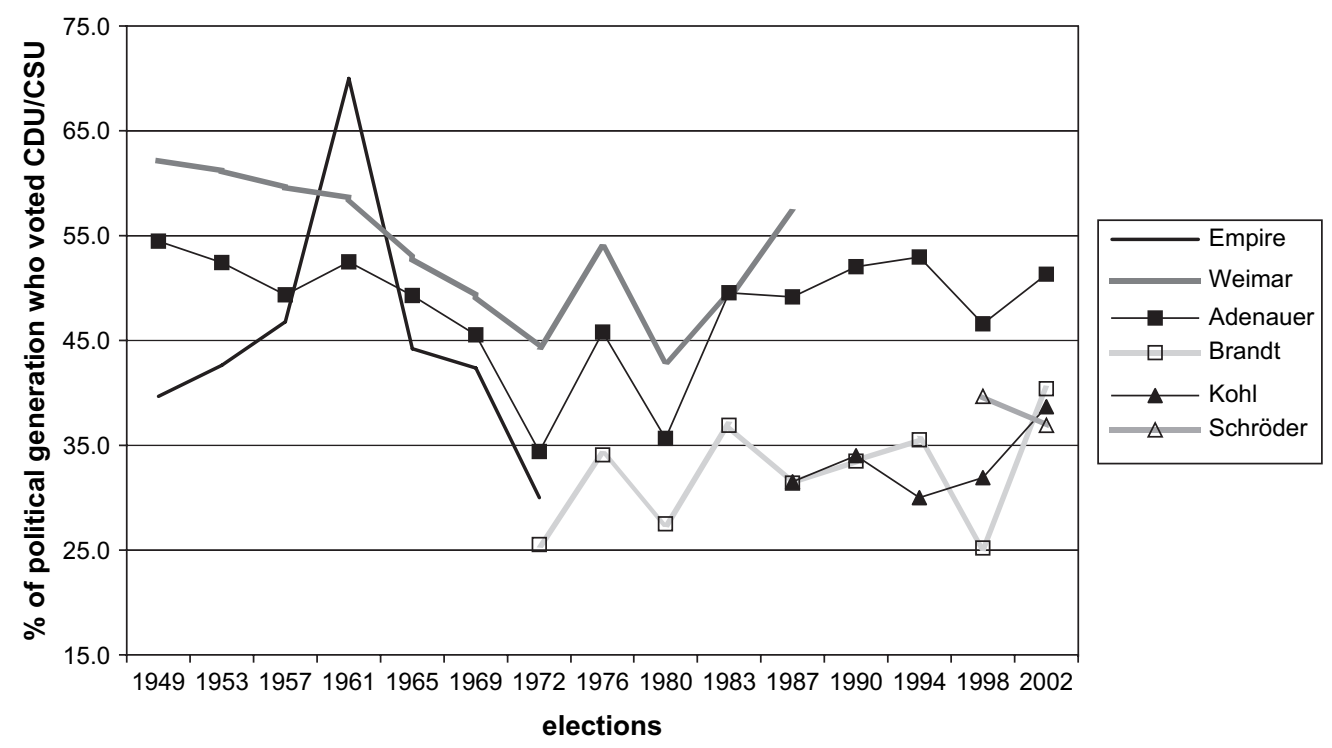

Fig. 6. Proportion of political generations who vote CDU/CSU in German elections, 1949-2002. Source: own calculation according to German election studies, 1961-1998, and Politbarometer 2002.

be due to sampling error or systematic variance within each political generation.

For this early British period, the political generation hypothesis seems to hold true. However, this test also suffers from the difficulties of separating adequate political generations and making correct predictions about their party choice. The 1945 Cohort and the 1966-1979 Cohort stand out most clearly as having different party preferences from the respective preceding generations. With regard to the three major parties, these two generations are significantly different from their immediate predecessors, although I was unable to make a correct prediction in every instance.

In the second British period, there is less variation with regard to adjacent generations, and very few generation dummies show significant coefficients. In seven out of 16 instances (Table 5), our predictions were right in terms of the change in the point estimates, meaning that the number of correct predictions was about the same as in the early British period. Nonetheless, the number of significant, correct predictions is zero. This means that there is much more variation within political generations in the second British period than in the first. Also revealing are the coefficients of the three generations that overlap in both periods (1945 Cohort, 1951-1966 Cohort and 1966-1979 Cohort). Relative to the baseline of the 1966-1979 Cohort, the two other generations look different for the two time periods with respect to the Tory or Labour vote. Where there were strong differences to the baseline generation in the first period, these generations are no longer any different from it in the second period. Knowing which election was the first in which a voter was eligible to vote tells you much less in the later British period.

There are some significant age coefficients in the second period. The Labour party and 'other parties' are being voted for less by older voters, regardless of their generational membership. The finding for the Labour party could be seen as evidence of a voting pattern among older people in which they favour economically more conservative parties. However, we do not see the opposite result for the Conservatives since there is no positive coefficient of age in the regression of the Conservative Party. The result for the other parties could be interpreted as evidence supporting the hypothesis of larger-party advantage, but that will be tested separately.

In the full sample regressions, which cover the entire period from 1964 to 2001, we see generational coefficients, the magnitude of which is between the results for the early period and the later period. Whereas the early British period shows strong, significant differences and the later period exhibits little to no generational variation, the results of the third model lie somewhere in the middle. The results for the whole period are exactly what we expect if the differences between early and late periods exist. The creation of two shorter time periods in the longitudinal analysis did not produce artificial results that might have been caused by the collinearity structure of our independent variables. The results of the full sample thus justify 
Table 4

Logistic regression models of party choice in Britain, 1964-1979, 1979-2001, and 1964-2001

\begin{tabular}{|c|c|c|c|c|c|c|c|c|c|c|c|c|}
\hline \multirow[b]{3}{*}{ Survey period } & \multicolumn{12}{|c|}{ Dependent variable: voted in last parliamentary election for one party election versus voted for another } \\
\hline & \multicolumn{3}{|l|}{ Labour } & \multicolumn{3}{|l|}{ Cons } & \multicolumn{3}{|l|}{ Liberals } & \multicolumn{3}{|l|}{ Others } \\
\hline & 1964-1979 & $1979-2001$ & $1964-2001$ & $1964-1979$ & 1979-2001 & 1964-2001 & $1964-1979$ & $1979-2001$ & $1964-2001$ & $1964-1979$ & $1979-2001$ & $1964-2001$ \\
\hline Valid $N$ & 8877 & 15,952 & 23,276 & 8877 & 15,952 & 23,276 & 7211 & 15,952 & 21,610 & 8877 & 15,952 & 23,276 \\
\hline Pseudo $R^{2}$ & 0.115 & 0.082 & 0.101 & 0.098 & 0.073 & 0.083 & 0.039 & 0.032 & 0.044 & 0.075 & 0.079 & 0.095 \\
\hline Constant & $\begin{array}{l}0.03 \\
(0.12)\end{array}$ & $\begin{array}{l}-0.49^{* * *} \\
(0.12)\end{array}$ & $\begin{array}{l}-0.41^{* * *} \\
(0.08)\end{array}$ & $\begin{array}{l}-0.59^{* * *} \\
(0.12)\end{array}$ & $\begin{array}{l}0.11 \\
(0.33)\end{array}$ & $\begin{array}{l}-0.19^{*} \\
(0.08)\end{array}$ & $\begin{array}{l}-1.97^{\text {*** }} \\
(0.17)\end{array}$ & $\begin{array}{l}-2.10^{* * *} \\
(0.11)\end{array}$ & $\begin{array}{l}-1.94^{\text {*** }} \\
(0.11)\end{array}$ & $\begin{array}{l}-3.40 \\
(0.62)\end{array}$ & $\begin{array}{l}-3.46^{\text {*** }} \\
(0.30)\end{array}$ & $\begin{array}{l}-3.24^{* * *} \\
(0.34)\end{array}$ \\
\hline \multicolumn{13}{|l|}{ Political generations } \\
\hline Victorian & $\begin{array}{l}-0.64^{* * *} \\
(0.16)\end{array}$ & & $\begin{array}{l}-0.47^{* * *} \\
(0.15)\end{array}$ & $\begin{array}{l}0.95^{* * *} \\
(0.16)\end{array}$ & & $\begin{array}{l}0.78^{* * *} \\
(0.14)\end{array}$ & $\begin{array}{l}-0.55 \\
(0.28)\end{array}$ & & $\begin{array}{l}-0.46 \\
(0.26)\end{array}$ & $\begin{array}{l}-0.05 \\
(1.23)\end{array}$ & & $\begin{array}{l}0.23 \\
(0.81)\end{array}$ \\
\hline Inter-War Cohort & $\begin{array}{l}-0.53^{* * *} \\
(0.09)\end{array}$ & & $\begin{array}{l}-0.36^{* * *} \\
(0.06)\end{array}$ & $\begin{array}{l}0.81^{\text {*** }} \\
(0.09)\end{array}$ & & $\begin{array}{l}0.65^{* * *} \\
(0.06)\end{array}$ & $\begin{array}{l}-0.49^{* * *} \\
(0.13)\end{array}$ & & $\begin{array}{l}-0.41^{* * *} \\
(0.09)\end{array}$ & $\begin{array}{l}0.01 \\
(0.80)\end{array}$ & & $\begin{array}{l}0.14 \\
(0.41)\end{array}$ \\
\hline 1945 Cohort & $\begin{array}{l}-0.40^{* * *} \\
(0.09)^{* * *}\end{array}$ & $\begin{array}{l}0.05 \\
(0.06)\end{array}$ & $\begin{array}{l}-0.19^{* * *} \\
(0.05)\end{array}$ & $\begin{array}{l}0.55^{* * *} \\
(0.09)\end{array}$ & $\begin{array}{l}0.08 \\
(0.12)\end{array}$ & $\begin{array}{l}0.37^{* * *} \\
(0.05)\end{array}$ & $\begin{array}{l}-0.15 \\
(0.12)\end{array}$ & $\begin{array}{l}-0.01 \\
(0.07)\end{array}$ & $\begin{array}{l}-0.11 \\
(0.07)\end{array}$ & $\begin{array}{l}-0.28 \\
(0.53)\end{array}$ & $\begin{array}{l}-0.27 \\
(0.18)\end{array}$ & $\begin{array}{l}-0.12 \\
(0.26)\end{array}$ \\
\hline 1951-1966 Cohort & $\begin{array}{l}-0.22^{* *} \\
(0.08)\end{array}$ & $\begin{array}{l}0.02 \\
(0.05)\end{array}$ & $\begin{array}{l}-0.10^{* * *} \\
(0.05)\end{array}$ & $\begin{array}{l}0.37^{* * *} \\
(0.08)\end{array}$ & $\begin{array}{l}0.08 \\
(0.05)\end{array}$ & $\begin{array}{l}0.27^{* * *} \\
(0.05)\end{array}$ & $\begin{array}{l}-0.25^{*} \\
(0.12)\end{array}$ & $\begin{array}{l}-0.11 \\
(0.06)\end{array}$ & $\begin{array}{l}-0.20 \\
(0.06)\end{array}$ & $\begin{array}{l}0.07 \\
(0.31)\end{array}$ & $\begin{array}{l}-0.03 \\
(0.12)\end{array}$ & $\begin{array}{l}0.04 \\
(0.15)\end{array}$ \\
\hline $\begin{array}{l}\text { 1966-1979 Cohort } \\
\text { (baseline) }\end{array}$ & 0.00 & 0.00 & 0.00 & 0.00 & 0.00 & 0.00 & 0.00 & 0.00 & 0.00 & 0.00 & 0.00 & 0.00 \\
\hline Thatcher's Children & & $\begin{array}{l}0.11 \\
(0.07)\end{array}$ & $\begin{array}{l}0.19^{* * *} \\
(0.06)\end{array}$ & & $\begin{array}{l}0.00 \\
(0.16)\end{array}$ & $\begin{array}{l}0.05 \\
(0.05)\end{array}$ & & $\begin{array}{l}-0.23 \\
(0.07)\end{array}$ & $\begin{array}{l}-0.30^{* * *} \\
(0.06)\end{array}$ & & $\begin{array}{l}-0.28^{*} \\
(0.14)\end{array}$ & $\begin{array}{l}-0.41^{* *} \\
(0.15)\end{array}$ \\
\hline Blair's Children & & $\begin{array}{l}-0.03 \\
(0.17) \\
\end{array}$ & $\begin{array}{l}0.15 \\
(0.16) \\
\end{array}$ & & $\begin{array}{l}0.10 \\
(0.28) \\
\end{array}$ & $\begin{array}{l}0.08 \\
(0.16) \\
\end{array}$ & & $\begin{array}{l}0.01 \\
(0.20)\end{array}$ & $\begin{array}{l}-0.08 \\
(0.20)\end{array}$ & & $\begin{array}{l}-0.88^{*} \\
(0.35) \\
\end{array}$ & $\begin{array}{l}-1.09^{* *} \\
(0.38) \\
\end{array}$ \\
\hline Age & \begin{tabular}{|l|}
0.00 \\
$(0.00)$ \\
\end{tabular} & $\begin{array}{l}-0.005^{* * *} \\
(0.00)\end{array}$ & $\begin{array}{l}0.00 \\
(0.00) \\
\end{array}$ & $\begin{array}{l}0.00 \\
(0.00) \\
\end{array}$ & $\begin{array}{l}0.00 \\
(0.01) \\
\end{array}$ & $\begin{array}{l}0.00 \\
(0.00) \\
\end{array}$ & $\begin{array}{l}0.00 \\
(0.00) \\
\end{array}$ & $\begin{array}{l}0.00 \\
(0.00) \\
\end{array}$ & $\begin{array}{l}0.00 \\
(0.00) \\
\end{array}$ & $\begin{array}{l}-0.02 \\
(0.02) \\
\end{array}$ & $\begin{array}{l}-0.02^{* *} \\
(0.00)\end{array}$ & $\begin{array}{l}-0.02^{* *} \\
(0.01)\end{array}$ \\
\hline Education & $\begin{array}{l}-0.47^{\text {*** }} \\
(0.03)\end{array}$ & $\begin{array}{l}-0.14^{* * *} \\
(0.02)\end{array}$ & $\begin{array}{l}-0.24^{* * *} \\
(0.02)\end{array}$ & $\begin{array}{l}0.31^{\text {*** }} \\
(0.03)\end{array}$ & $\begin{array}{l}0.02 \\
(0.02)\end{array}$ & $\begin{array}{l}0.12^{* * *} \\
(0.01)\end{array}$ & $\begin{array}{l}0.15^{* * *} \\
(0.04)\end{array}$ & $\begin{array}{l}0.17 \\
(0.02)\end{array}$ & $\begin{array}{l}0.17^{\text {*** }} \\
(0.02)\end{array}$ & $\begin{array}{l}0.14 \\
(0.09)\end{array}$ & $\begin{array}{l}-0.06 \\
(0.03)\end{array}$ & $\begin{array}{l}-0.03 \\
(0.03)\end{array}$ \\
\hline Religiosity & $\begin{array}{l}-0.07^{* * *} \\
(0.02)\end{array}$ & $\begin{array}{l}-0.05^{* * *} \\
(0.01)\end{array}$ & $\begin{array}{l}-0.06^{* * *} \\
(0.01)\end{array}$ & $\begin{array}{l}0.04 \\
(0.02)\end{array}$ & $\begin{array}{l}0.04^{* *} \\
(0.01)\end{array}$ & $\begin{array}{l}0.03 \\
(0.01)\end{array}$ & $\begin{array}{l}0.08^{* *} \\
(0.03)\end{array}$ & $\begin{array}{l}0.00 \\
(0.01)\end{array}$ & $\begin{array}{l}0.03^{* *} \\
(0.01)\end{array}$ & $\begin{array}{l}-0.03 \\
(0.10)\end{array}$ & $\begin{array}{l}0.05 \\
(0.03)\end{array}$ & $\begin{array}{l}0.06^{*} \\
(0.03)\end{array}$ \\
\hline Female & $\begin{array}{l}-0.15^{\text {*** }} \\
(0.05)\end{array}$ & $\begin{array}{l}-0.06 \\
(0.04)\end{array}$ & $\begin{array}{l}-0.08^{*} \\
(0.03)\end{array}$ & $\begin{array}{l}0.04 \\
(0.05)\end{array}$ & $\begin{array}{l}0.03 \\
(0.04)\end{array}$ & $\begin{array}{l}0.02 \\
(0.03)\end{array}$ & $\begin{array}{l}0.07 \\
(0.08)\end{array}$ & $\begin{array}{l}-0.05 \\
(0.05)\end{array}$ & $\begin{array}{l}-0.02 \\
(0.04)\end{array}$ & $\begin{array}{l}0.71^{* * *} \\
(0.17)\end{array}$ & $\begin{array}{l}0.29 \\
(0.08)\end{array}$ & $\begin{array}{l}0.41^{* * *} \\
(0.08)\end{array}$ \\
\hline $\begin{array}{l}\text { Trade union } \\
\text { membership }\end{array}$ & $\begin{array}{l}1.00^{* * *} \\
(0.06)\end{array}$ & $\begin{array}{l}0.47^{* * *} \\
(0.04)\end{array}$ & $\begin{array}{l}0.74^{* * *} \\
(0.04)\end{array}$ & $\begin{array}{l}-0.96^{* * *} \\
(0.06)\end{array}$ & $\begin{array}{l}-0.58^{* * *} \\
(0.05)\end{array}$ & $\begin{array}{l}-0.74^{* * *} \\
(0.04)\end{array}$ & $\begin{array}{l}-0.21^{*} \\
(0.10)\end{array}$ & $\begin{array}{l}0.17 \\
(0.05)\end{array}$ & $\begin{array}{l}-0.02 \\
(0.05)\end{array}$ & $\begin{array}{l}0.11 \\
(0.16)\end{array}$ & $\begin{array}{l}0.11 \\
(0.09)\end{array}$ & $\begin{array}{l}0.09 \\
(0.08)\end{array}$ \\
\hline Council housing & $\begin{array}{l}1.08^{* * *} \\
(0.05)\end{array}$ & $\begin{array}{l}1.30^{* * *} \\
(0.05)\end{array}$ & $\begin{array}{l}1.19^{* * *} \\
(0.04)\end{array}$ & $\begin{array}{l}-1.07^{* * *} \\
(0.06)\end{array}$ & $\begin{array}{l}-1.32^{* * *} \\
(0.06)\end{array}$ & $\begin{array}{l}-1.21^{* * *} \\
(0.04)\end{array}$ & $\begin{array}{l}-0.44^{* * *} \\
(0.09)\end{array}$ & $\begin{array}{l}-0.31 \\
(0.06)\end{array}$ & $\begin{array}{l}-0.39^{* * *} \\
(0.06)\end{array}$ & $\begin{array}{l}0.57^{* * *} \\
(0.16)\end{array}$ & $\begin{array}{l}0.57 \\
(0.11)\end{array}$ & $\begin{array}{l}0.57^{* * *} \\
(0.09)\end{array}$ \\
\hline \multicolumn{13}{|l|}{ Election years } \\
\hline 1964 & $\begin{array}{l}0.46^{* * *} \\
(0.09)\end{array}$ & & $\begin{array}{l}0.49^{* * *} \\
(0.08)\end{array}$ & $\begin{array}{l}-0.36^{* * *} \\
(0.09)\end{array}$ & & $\begin{array}{l}-0.38^{* * *} \\
(0.08)\end{array}$ & $\begin{array}{l}-0.11 \\
(0.13)\end{array}$ & & $\begin{array}{l}-0.15 \\
(0.12)\end{array}$ & $\begin{array}{l}-1.24^{*} \\
(0.54)\end{array}$ & & $\begin{array}{l}-1.42^{* * *} \\
(0.51)\end{array}$ \\
\hline 1966 & $\begin{array}{l}0.67^{* * *} \\
(0.09)\end{array}$ & & $\begin{array}{l}0.69^{* * *} \\
(0.09)\end{array}$ & $\begin{array}{l}-0.46^{* * *} \\
(0.09)\end{array}$ & & $\begin{array}{l}-0.49^{* * *} \\
(0.09)\end{array}$ & $\begin{array}{l}-0.40^{* * *} \\
(0.14)\end{array}$ & & $\begin{array}{l}-0.44^{* * *} \\
(0.14)\end{array}$ & $\begin{array}{l}-0.68 \\
(0.46)\end{array}$ & & $\begin{array}{l}-0.84 \\
(0.44)\end{array}$ \\
\hline 1970 & $\begin{array}{l}0.64^{* * *} \\
(0.09)\end{array}$ & & $\begin{array}{l}0.52^{* * *} \\
(0.08)\end{array}$ & $\begin{array}{l}-0.30^{* * *} \\
(0.08)\end{array}$ & & $\begin{array}{l}-0.21^{* *} \\
(0.08)\end{array}$ & $\begin{array}{l}-0.68^{* * *} \\
(0.13)\end{array}$ & & $\begin{array}{l}-0.73^{* * *} \\
(0.13)\end{array}$ & $\begin{array}{l}0.35 \\
(0.29)\end{array}$ & & $\begin{array}{l}0.33 \\
(0.28)\end{array}$ \\
\hline
\end{tabular}




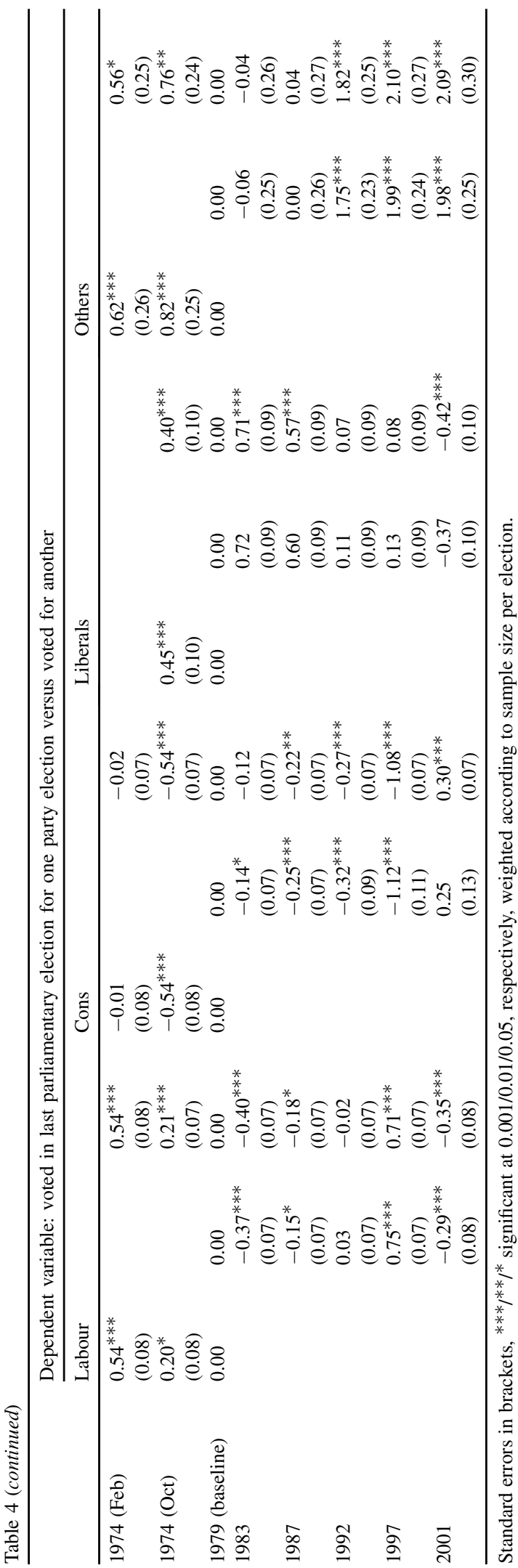

the strategy of splitting the data into two time periods in order to capture the impact of de-alignment.

How big are the predicted differences between older and younger voters in Britain? Looking back at Table 4, we see that the differences between generations are as large as many period election effects. Table 6 reports the predicted probabilities for two exemplary election years, 1964 (early period) and 2001 (late period), and for a 70 -year-old and a 30 -year-old voter. The predictions take into consideration election swings as well as generational and age differences. All other differences between age groups are held constant. For example, the predicted probability that a young voter votes for Labour in 1964 is 55\%, compared with a 39\% probability for the older voter. This represents a difference of $16 \%$. In 2001, however, the difference between a younger and an older voter is predicted to be only $6 \%$. The change from 16 and $6 \%$ results from the weakening importance of generational differences. A 70year-old in 1964 belonged to the Victorian Generation, which showed a much lesser likelihood to vote for Labour. This finding conforms to the fact that Labour was still very weak during the time of the voter's early political socialisation. A 30-year-old in 1964 belonged to the 1951-1966 Cohort, which exhibited a much greater likelihood to vote Labour because that party had, by then, become part of the government on a regular basis. In 2001, the generational difference between a 70-year-old (1945 Cohort) and a 30-year-old (Thatcher's Children) hardly mattered anymore. Due to the vanishing importance of generational differences, the predictions in 2001 differ much less for the two exemplary voters than in 1964 . The only exception is the category of 'other parties', a result of the growing importance of regionalist parties in Wales and Scotland. In sum, older and younger voters become more alike in the British case. The grey vote becomes less distinguishable from the vote of younger age groups.

Taken together, these findings seem to suggest that, after de-alignment had started, generational differences caused by varying socialisation experience at young age mattered less than they had before. From a perspective that focuses on differences between age groups, it looks as if the increased volatility of voters, defined as members of certain generations, has made the grey vote more similar to others. If the degree of de-alignment really played a role, we should now see results for West Germany that are somewhere in the middle of the results between the early and the late British periods. De-alignment in West Germany should be stronger than in the early British period and weaker than in the later British period. 
Table 5

Accuracy of generational hypotheses in Britain

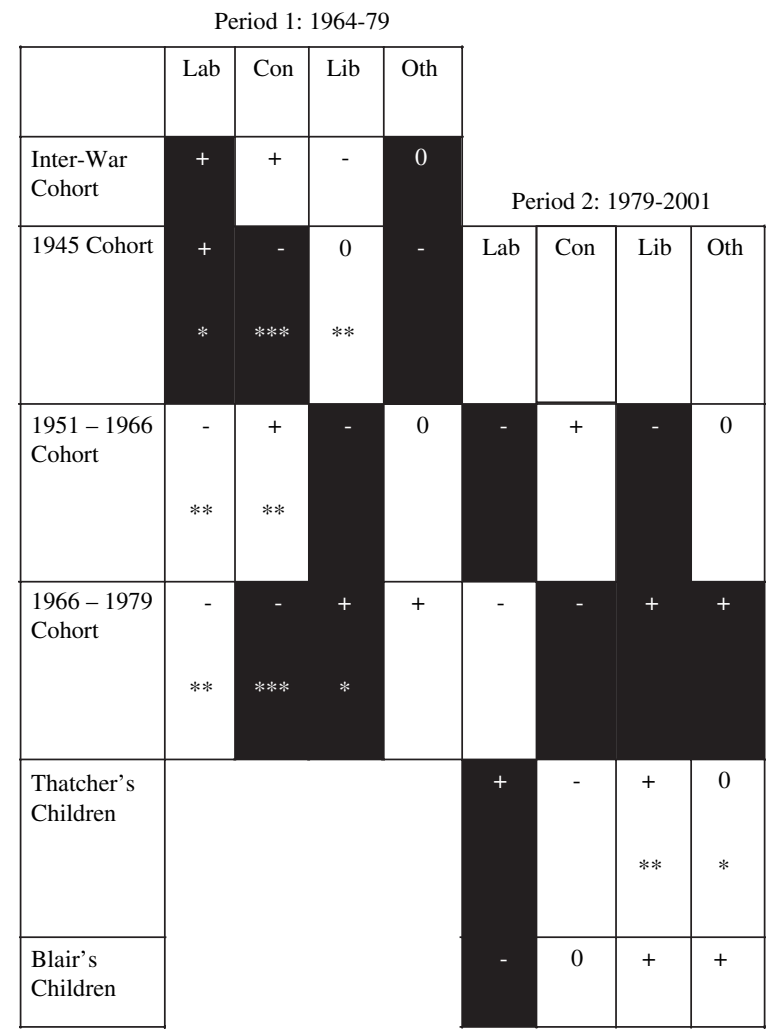

Black boxes stand for confirmed expectation as to a predicted movement relative to the previous generation with regard to the point estimates of the coefficients. Stars indicate the significant difference $\left(^{*}\right.$, $0.05 ; * *, 0.01 ; * * *, 0.001)$ of a generational coefficient in comparison with the coefficient of the preceding generation.

The German data set (Table 7) contains about 10 times as many observations as the British data. Therefore, I will use a confidence level of $99 \%$ as a minimum instead of $95 \%$.

Table 6

Predicted probabilities that a 30-year-old and a 70-year-old vote for Labour, Conservatives, Liberals or for other parties in 1980 or 2002

\begin{tabular}{llrrr}
\hline Party & $\begin{array}{l}\text { Election } \\
\text { year }\end{array}$ & 70-Year-old & 30-Year-old & Difference \\
\hline Labour & 1964 & 39 & 55 & -16 \\
& 2001 & 25 & 31 & -6 \\
Cons & 1964 & 50 & 28 & 22 \\
& 2001 & 57 & 53 & 4 \\
Lib & 1964 & 8 & 14 & -6 \\
& 2001 & 10 & 9 & 1 \\
\multirow{2}{*}{ Others } & 1964 & 0 & 1 & -1 \\
& 2001 & 7 & 10 & -3 \\
\hline
\end{tabular}

All other variables held constant at their means. For 1964, I use the model of the early period. For 2001, I use the model of the later period.
We can test 16 predictions about the relative change of political generations with regard to their party preferences vis-à-vis the preceding generations. Our expectations are confirmed in eight out of 16 instances (Table 8). Our predictions were completely wrong about the latest Schröder Generation, a finding that suggests that this generation is not well-defined. The overall predictive power of the relative generational predictions is as mediocre as for the British context. However, the correctly predicted changes in point estimates are supported by favourable significance tests, meaning that we can be much more confident about the direction of impact for the West German than for the British model (which probably directly results from the higher number of observations in the West German data set).

Overall, the magnitude of differences between political generations is between the levels we have seen in both British periods, so that the importance of the de-alignment context gains further credibility. Also, the New Politics hypothesis is confirmed by the finding that the Greens found little backing in the earliest Weimar and Adenauer generations. The Green party found most of its supporters in the Brandt Generation. Then their electoral fortunes declined in the Kohl and Schröder generations. This is in tune with Inglehart's hypothesis. Economic downturns occurred just before the Kohl and Schröder eras when those generation members were still teenagers ineligible to vote (in the 1973 and early 1990s). The experiences of these downturns just before these people came of political age explain why this generation exhibits post-materialist values less often and therefore was less likely to vote for the Greens, relative to the Brandt Generation, who grew up during the German Wirtschaftswunder.

On the whole, the coefficients of the age variable in the German models are significant in more instances than in the British model. If the economic conservatism hypothesis was correct, we would need to see an increase in the age variation for the FDP, the economically most conservative party, and the opposite pattern for the SPD, the most progressive one. These variations do not exist. In contrast, the FDP even shows significant variation in the opposite direction. Thus, there is again no evidence for growing economic conservatism in party choice among ageing voters.

How big are the predicted differences between older and younger voters in West Germany? Table 9 reports the predicted probabilities for an average 70-year-old and a 30-year-old voter in the 1980 and 2002 elections. The Christian Democrats show the strongest differences 
Table 7

Logistic regression models of party choice in West Germany, 1977/1980-2002

\begin{tabular}{|c|c|c|c|c|}
\hline & \multicolumn{4}{|c|}{ Dependent variable: would vote for one party versus would vote for another } \\
\hline & SPD & $\mathrm{CDU} / \mathrm{CSU}$ & FDP & Greens \\
\hline Valid $N$ & 242,409 & 242,409 & 242,409 & 216,181 \\
\hline Pseudo $R^{2}$ & 0.058 & 0.081 & 0.036 & 0.144 \\
\hline Constant & $0.56^{* * *}(0.06)$ & $-1.05^{* * *}(0.06)$ & $-2.83^{* * *}(0.11)$ & $-3.44^{* * *}(0.16)$ \\
\hline \multicolumn{5}{|l|}{ Political generations } \\
\hline Weimar (baseline) & 0.00 & 0.00 & 0.00 & 0.00 \\
\hline Adenauer & $-0.09^{* * *}(0.02)$ & $0.22^{* * *}(0.02)$ & $0.24^{* * *}(0.05)$ & $0.11(0.11)$ \\
\hline Brandt & $0.07^{*}(0.04)$ & $-0.08^{*}(0.04)$ & $0.06(0.07)$ & $0.57^{* * *}(0.12)$ \\
\hline Kohl & $0.01(0.04)$ & $-0.01(0.05)$ & $-0.15(0.09)$ & $0.11(0.14)$ \\
\hline Schröder & $-0.21^{* * *}(0.06)$ & $0.28^{* * *}(0.06)$ & $0.01(0.13)$ & $-0.37^{*}(0.16)$ \\
\hline Age & \begin{tabular}{|l}
$0.00(0.00)$ \\
\end{tabular} & $0.01^{* * *}(0.00)$ & $-0.003^{*}(0.001)$ & $-0.04^{* * *}(0.00)$ \\
\hline Education & $-0.26^{* * *}(0.01)$ & $-0.04^{* * *}(0.01)$ & $0.38^{* * *}(0.01)$ & $0.61^{* * *}(0.01)$ \\
\hline Trade union membership & $0.81^{* * *}(0.01)$ & $-0.79^{* * *}(0.01)$ & $-0.53^{* * *}(0.02)$ & $0.07^{* * *}(0.02)$ \\
\hline Religiosity & $-0.26^{* * *}(0.00)$ & $0.34^{* * *}(0.00)$ & $-0.05^{* * *}(0.01)$ & $-0.17^{* * *}(0.01)$ \\
\hline Female & $-0.12^{* * *}(0.01)$ & $0.17^{* * *}(0.01)$ & $0.01^{* * *}(0.02)$ & $-0.32^{* * *}(0.02)$ \\
\hline \multicolumn{5}{|c|}{ Year dummies (1977/1980-2002), selected coefficients } \\
\hline 1977 & 0.00 & 0.00 & 0.00 & \\
\hline 1980 & $0.28^{* * *}(0.03)$ & $-0.31^{* * *}(0.03)$ & $-0.25^{* * *}(0.05)$ & 0.00 \\
\hline 1990 & $0.11^{* * *}(0.03)$ & $-0.20^{* * *}(0.03)$ & $-0.44^{* * *}(0.06)$ & $0.61^{* * *}(0.07)$ \\
\hline 2002 & $-0.03(0.04)$ & $-0.15^{* * *}(0.04)$ & $-0.44^{* * *}(0.06)$ & $1.09^{* * *}(0.07)$ \\
\hline
\end{tabular}

Standard errors in brackets, ${ }^{* * *} / * * /^{*}$ significant at $0.001 / 0.01 / 0.05$, respectively, weighted according to sample size per election.

of $10 \%$ in 1980 and $14 \%$ in 2002 . However, the most remarkable differences can be seen for the Green party where the generational differences mean that even in 2002 , the probability that an older voter would vote for that party was one-fifth $(2 \%)$ of the probability that a younger voter would $(10 \%)$.

Table 8

Accuracy of generational hypotheses in West Germany

\begin{tabular}{|c|c|c|c|c|}
\hline & SPD & $\begin{array}{l}\mathrm{CDU} / \\
\mathrm{CSU}\end{array}$ & FDP & Greens \\
\hline Adenauer & $\begin{array}{c}0 \\
* * *\end{array}$ & $\begin{array}{c}+ \\
* * *\end{array}$ & $\begin{array}{c}+ \\
* * *\end{array}$ & 0 \\
\hline Brandt & $\begin{array}{c}+ \\
* * *\end{array}$ & $\begin{array}{c}- \\
* * *\end{array}$ & $\begin{array}{c}0 \\
* * *\end{array}$ & $\begin{array}{c}+ \\
* * *\end{array}$ \\
\hline Kohl & $\begin{array}{c}- \\
* * *\end{array}$ & $\begin{array}{c}+ \\
* * *\end{array}$ & $\begin{array}{c}- \\
* * *\end{array}$ & $\begin{array}{c}+ \\
* * *\end{array}$ \\
\hline Schröder & $\begin{array}{c}+ \\
* * *\end{array}$ & $\begin{array}{c}- \\
* * *\end{array}$ & $\begin{array}{l}0 \\
*\end{array}$ & $\begin{array}{c}+ \\
* * *\end{array}$ \\
\hline
\end{tabular}

Black boxes stand for confirmed expectation as to a predicted movement relative to the previous generation with regard to the point estimates of the coefficients. Stars indicate the significant difference $(*, 0.05 ; * *, 0.01 ; * * *, 0.001)$ of a generational coefficient in comparison with the coefficient of the preceding generation.
Overall, the party-by-party analysis of Britain and West Germany enabled us to test the generational hypotheses (political generation and New Politics). It gave us some evidence on the nature of the life-cycle hypotheses. Economic conservatism can be ruled out as an explanatory factor because the parties that are most extreme in terms of their economic stance do not show the variation between age groups that we would expect. For instance, neither the German FDP nor the Tories show a general advantage among older voters. That still leaves us to run decisive tests on the hypothesis of larger-party advantage in order to make sense of the residual variation between age groups once we control for generational and compositional factors.

Table 9

Predicted probabilities that a 30-year-old and a 70-year-old vote for SPD, CDU/CSU, FDP or Greens in 1980 or 2002

\begin{tabular}{lllll}
\hline Party & Election year & 70-Year-old & 30-Year-old & Difference \\
\hline SPD & 1980 & 47 & 48 & -1 \\
& 2002 & 37 & 39 & -2 \\
CDU/CSU & 1980 & 41 & 31 & 10 \\
& 2002 & 51 & 36 & 14 \\
FDP & 1980 & 7 & 8 & -1 \\
& 2002 & 7 & 6 & 1 \\
\multirow{3}{*}{ Greens } & 1980 & 1 & 6 & -5 \\
& 2002 & 2 & 10 & -8 \\
\hline
\end{tabular}

All other variables are held constant at their means. 
Table 10

Logistic regression models for Britain and West Germany

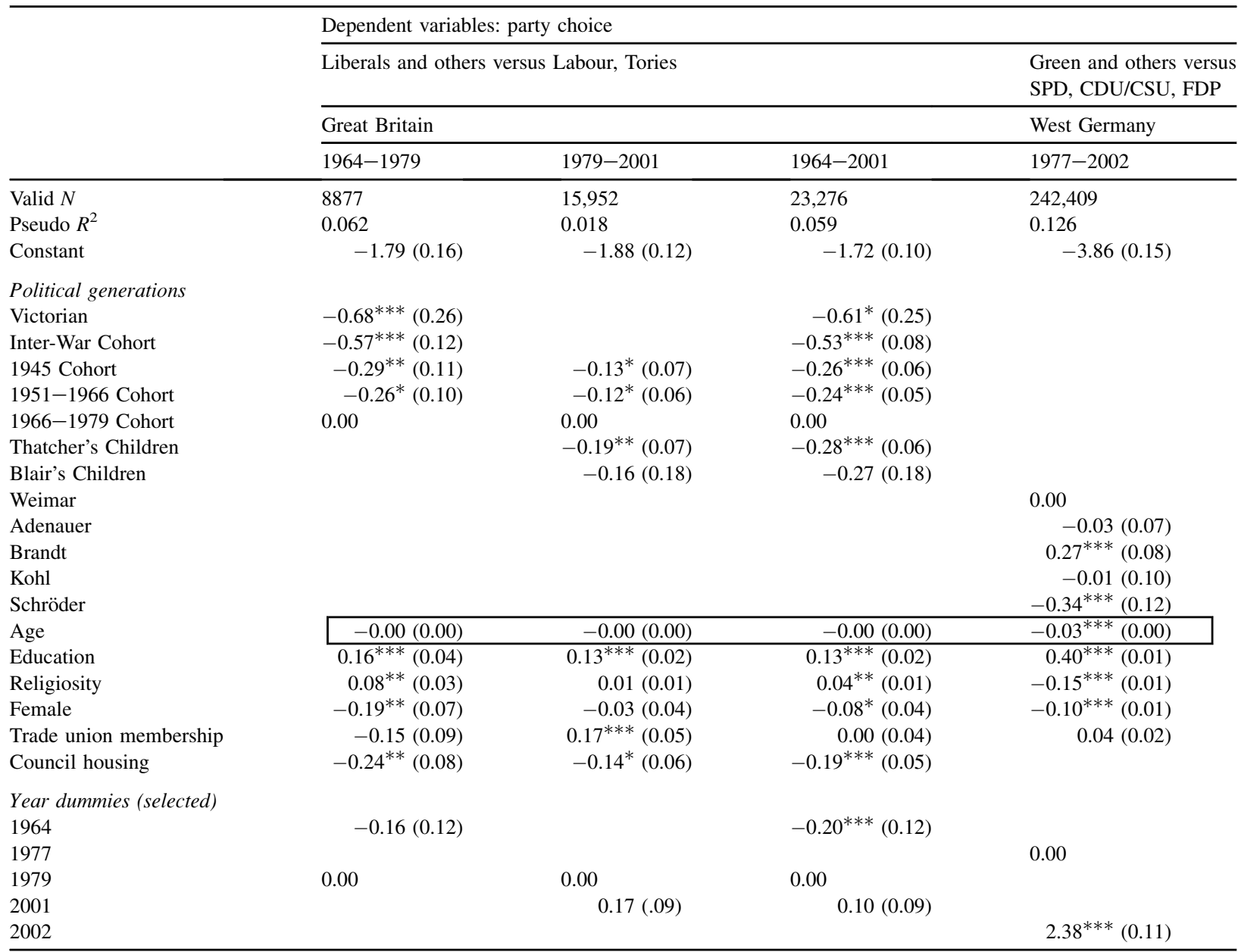

Weighted according to sample size per election.

Table 10 shows four regressions. For Britain, the dependent variable is coded 1 if respondents voted for the Liberals or any other small party and 0 if they voted for Labour or the Tories. For West Germany, the dependent variable is coded 1 if respondents voted for the Greens or any of the small parties and 0 if they voted for the SPD, CDU/CSU or the FDP, each of which have had long tenures of governmental participation in German post-war history. There are again controls for education, religious practice, gender, trade union membership and, for Britain, council housing.

The British models show no significant age effects in the predicted direction for any of the periods. The West German one, in contrast, shows a decreasing likelihood to vote for the Greens or other parties among older people, in accordance to the hypothesis of larger-party advantage. The predicted probability to vote for a smaller party is only $2 \%$ for someone who was 70 years old in 1980 and $6 \%$ for someone who was 30 years old with only year and age varying. In 2002, the predicted probability was 6 and $19 \%$. Those numbers represent sizable differences between the grey vote and the vote of other age groups. However, since we failed to find evidence for the two British periods, we find no general support for the hypothesis of larger-party advantage as it was formulated at the beginning of the article. It could be that the evidence for West Germany is measuring something that is unique to the German case, maybe a frequent occurrence of anti-establishment parties among the category of 'smaller parties'. The difference between the two countries cannot lie in de-alignment. For one, the generation dummies 
capture the growth in vote share among new, smaller parties. For another, if we were to order the three contexts of period/country constellations according to the strength of de-alignment, West Germany would fall in the middle. So neither the most aligned system, Britain from 1964 to 1979, nor the most dealigned system, Britain from 1979 to 2001, shows the age advantage for bigger parties. Instead, I suggest a new hypothesis for future testing. The reason might lie in the difference in electoral systems. In Britain, voting for a smaller party does not make any sense in most constituencies because the candidate is not likely to win. Therefore, even if larger parties leave a stronger impression on older voters than on younger ones, the younger ones might be as likely to vote for the latter because there is no instrumental sense to vote for smaller parties. Thus, we would not expect to see a measurable difference. In Germany by contrast, there is a stronger incentive to vote for smaller parties because the electoral system of proportional representation guarantees that no vote is 'wasted'. If this finding would generally hold true, party systems with low electoral thresholds should show that younger people are more likely to vote for smaller parties that do not have a history of governmental participation.

\section{Conclusions}

There are no simple, general effects that determine the party choice of older voters. Instead, it is rather a mixture of macrofactors, such as the nature of the party system, and the combination of life-cycle and generational effects that explain the differences between younger and older voters.

Two out of the four general hypotheses can be rejected or confirmed without reservations through the analysis of West Germany and Britain. Older people are not more likely to vote economically conservative. Moreover, the growing dimension of New Politics socialises younger cohorts into voting for New Politics parties, such as the Greens in West Germany. Thus, older voters today are still less likely to vote for these parties, although that may change as the generation born right after the war, the Brandt Generation in West Germany, starts to retire.

Political-generational effects are also present but seem to be a correlate of the state of de-alignment in the party system. The more de-aligned a party system is, the smaller the differences are between socialisation experiences in early adulthood because of growing electoral volatility. As a consequence, for instance, the older voters in recent British elections have behaved much more like younger voters than they have in the past because generational differences have ceased to matter.

One life-cycle hypothesis finds ambiguous evidence suggesting that a newly formulated hypothesis could hold. The conditions can only be proposed here; more research is needed to test them. Older people seem to build up a stronger preference for larger or governmental parties over their lifetimes, relative to younger voters. But this has noticeable implications only in party systems that have proportional representation where there is some general instrumental sense to vote for smaller parties.

These findings have implications for the literature on political behaviour as well as for the growing body of literature that discusses the political consequences of ageing electorates. It is the comparative analysis that research into age effects of political behaviour must look into. The behaviour of age groups cannot be analysed without a stronger reference to the structural factors of the macrocontext, i.e. the party system. So far, the literature focussed on single-country analyses of voting choice and age-related effects. Also, the article demonstrates that predictions of specific generational effects that are deducted beforehand are possible. Admittedly, the estimation of generational effects brought to light difficulties in separating them and making correct predictions. The noise within each generation poses additional conceptual and statistical problems that only extremely large data sets, like the accumulated monthly Politbarometer, can ease. However, trying to make predictions is still more illuminating and theoretically satisfactory than just stating the existence of these effects ex post.

The evidence also indicates that ageing democracies will neither show a simple pattern that confirms life-cycle regularities, nor a simple pattern produced by the sequence of political generations. Simplistic notions of the kind suggesting that ageing democracies will face insurmountable political blockades are not warranted.

Further research into the behaviour of older voters should aim at disentangling the importance of the effects identified here vis-à-vis specific policy issues of old age that are on the political agenda, such as public pensions. Furthermore, we need more research explaining the exact causal chain that makes older people grow more favourable toward larger parties in certain party systems. 


\section{Appendix}

\begin{tabular}{|c|c|c|c|c|c|c|}
\hline Variable name & Survey question & Answer categories & Min & Max & Mean & $\begin{array}{l}\text { Std. } \\
\text { deviation }\end{array}$ \\
\hline \multicolumn{7}{|l|}{ Politbarometer } \\
\hline Age & Derived from v55 and v56 & $\begin{array}{l}\text { From } 1988 \text { on, respondents } \\
\text { indicated age in } 5 \text {-year categories }\end{array}$ & 17 & 97 & 46.08 & 16.77 \\
\hline Education & $\begin{array}{l}\text { Derived variable from v59 } \\
\text { and v60 }\end{array}$ & $\begin{array}{l}\text { No school diploma or still at school, } \\
1 \text { at least basic diploma (Hauptschule), } \\
\text { at least advanced diploma (Realschule), } \\
\text { A Levels, university degree }\end{array}$ & 1 & 5 & 2.63 & 0.83 \\
\hline Religiosity & $\begin{array}{l}\text { How often to you generally go to } \\
\text { church? (if respondent expressed } \\
\text { denominational membership) }\end{array}$ & $\begin{array}{l}\text { Never, rarely, once a year, every now } \\
\text { and then, almost every Sunday, } \\
\text { every Sunday }\end{array}$ & 0 & 5 & 2.31 & 1.49 \\
\hline Sex & Coded by the interviewer & Male, female & 1 & 2 & 1.52 & 0.50 \\
\hline Smalvotefdp & $\begin{array}{l}\text { Respondent voted for the Greens } \\
\text { or another small party (not FDP) }\end{array}$ & & 0 & 1 & 0.11 & 0.31 \\
\hline $\begin{array}{l}\text { Trade union } \\
\text { membership }\end{array}$ & $\begin{array}{l}\text { Are you yourself or someone else } \\
\text { in your household member of } \\
\text { a trade union? }\end{array}$ & $\begin{array}{l}1=\text { at least one person in household } \\
\text { trade union member, } 0=\text { otherwise, } \\
\text { mean replaces missing values }\end{array}$ & 0 & 1 & 0.29 & 0.45 \\
\hline $\begin{array}{l}\text { Vote (if respondent } \\
\text { expressed } \\
\text { intention to vote) }\end{array}$ & $\begin{array}{l}\text { (If there was a national election } \\
\text { on Sunday) Which party would } \\
\text { you vote for? }\end{array}$ & SPD, CDU/CSU, FDP, Greens, Other & 1 & 5 & & \\
\hline Year of birth & Derived from age & & 1881 & 1983 & 1943.81 & 18.44 \\
\hline \multicolumn{7}{|c|}{ British Election Studies } \\
\hline Age, Year of birth & $\begin{array}{l}\text { Various formulation like Would } \\
\text { you say which year you are } \\
\text { born in? }\end{array}$ & & 18 & 99 & 47.05 & 17.61 \\
\hline Education & $\begin{array}{l}\text { Age at which respondent finished } \\
\text { school or full-time education }\end{array}$ & $\begin{array}{l}1=<16,2=16,3=17,4=18 \\
5>18, \text { mean replaces missing values }\end{array}$ & 1 & 5 & 1.94 & 1.19 \\
\hline Religiosity & $\begin{array}{l}\text { How often respondent attended } \\
\text { service }\end{array}$ & $\begin{array}{l}0=\text { never, } 1=\text { once a year, } 2=\text { more } \\
\text { than once a year, } 3=, 4=\text { once a month } \\
5=\text { several times a month, } 6=\text { more than } \\
\text { once a week mean replaces missing } \\
\text { values if no data in survey years }\end{array}$ & 0 & 6 & 2.80 & 1.64 \\
\hline Sex & Coded by the interviewer & Male, female & 1 & 2 & 1.53 & 0.50 \\
\hline $\begin{array}{l}\text { Council house } \\
\text { occupancy }\end{array}$ & $\begin{array}{l}\text { Whether respondent lives in rented } \\
\text { council house or flat }\end{array}$ & Mean replaces missing values & 0 & 1 & 0.25 & 0.41 \\
\hline $\begin{array}{l}\text { Trade union } \\
\text { membership }\end{array}$ & $\begin{array}{l}\text { Whether respondent is currently } \\
\text { member of trade union }\end{array}$ & $1=$ yes, $0=$ no & 0 & 1 & 0.25 & 0.40 \\
\hline Smalvote & $\begin{array}{l}\text { Respondent voted for the Liberals } \\
\text { or a small party }\end{array}$ & & 0 & 1 & 0.19 & 0.39 \\
\hline $\begin{array}{l}\text { Vote (if respondent } \\
\text { voted) }\end{array}$ & Which party did you vote for? & $\begin{array}{l}\text { Labour, Conservatives, } \\
\text { Liberals/Liberaldemocrats, Other }\end{array}$ & 1 & 4 & & \\
\hline
\end{tabular}

\section{References}

Barnes, S.H., 1989. Partisanship and electoral behavior. In: Jennings, M.K., Van Deth, J.W. (Eds.), Continuities in Political Action. De Gruyter, Berlin, pp. 235-274.

Binstock, R.H., Quadagno, J., 2001. Aging and politics. In: Binstock, R.H., George, L.K. (Eds.), Handbook of Aging and the Social Sciences. Academic Press, San Diego, pp. 333-351.

Braungart, R.G., Braungart, M.M., 1986. Life-course and generational politics. Annual Review of Sociology 12, 205-231.

Budge, I., 1999. Party policy and ideology: reversing the 1950s? In: Norris, P., Evans, G. (Eds.), Critical Elections. British Parties and Voters in Long-term Perspective. Sage, London, pp. 1-21.
Bürklin, W., 1987. Alte Wähler morgen: "Graue Panther" oder konservative Stammwähler der CDU? In: Deutsches Zentrum für Altersfragen (Ed.), Die ergraute Gesellschaft. DZA, Berlin, pp. 116-140.

Butler, D., Stokes, D., 1983 [1974]. Political Change in Britain. The Evolution of Electoral Choice. Macmillan, London/ Basingstoke.

Cain, B.E., Ferejohn, J.A., 1981. Party identification in the United States and Great Britain. Comparative Political Studies 14, 31-47.

Campbell, A., Converse, P.E., Miller, W.E., Stokes, D., 1960. The American Voter. John Wiley \& Sons, New York/London.

Cassel, C.A., 1999. Testing the converse party support model in Britain. Comparative Political Studies 32, 626-644. 
Claggett, W., 1981. Partisan acquisition v. partisan identity: life cycle, generation, and period effects. American Journal of Political Science 25, 193-214.

Clarke, H.D., LeDuc, L., Jenson, J., Pammett, J.H., 1979. Political Choice in Canada. McGraw-Hill Ryerson, Toronto.

Clarke, H.D., Sanders, D., Stewart, M.C., Whiteley, P.F., 2004. Political Choice in Britain. Oxford University Press, Oxford.

Converse, P.E., 1969. Of time and partisan stability. Comparative Political Studies 2, 139-172.

Converse, P.E., 1976. The Dynamics of Party Support: Cohortanalyzing Party Identification. Sage, Beverly Hills.

Crittenden, J., 1962. Aging and party affiliation. Public Opinion Quarterly 26, 651.

Cutler, N.E., 1977. Demographic, social-psychological, and political factors in the politics of aging: a foundation for research in 'political gerontology'. American Political Science Review 71, $1011-1025$

Danigelis, N.L., Cutler, S.J., 1991. Cohort trends in attitudes about law and order: who's leading the conservative wave? Public Opinion Quarterly 55, 24-49.

Falter, J.W., Gehring, U.W., 1998. Alter - ein neues Cleavage? In: Kaase, M., Klingemann, H.-D. (Eds.), Wahlen und Wähler: Analysen aus Anlass der Bundestagswahl 1994. Westdeutscher Verlag, Opladen, pp. 463-504.

Franklin, M.N., 1992. The decline in cleavage politics. In: Franklin, M.N., Mackie, T.T., Valen, H. (Eds.), Electoral Change. Responses to Evolving Social and Attitudinal Structures in Western Countries. Cambridge University Press, Cambridge, pp. $33-57$

Gehring, U.W., 1994. Die SPD - Partei der Zukunft? Eine Kohortenanalyse der Bundestagswahlen 1969-1990. In: Klingemann, H.-D., Kaase, M. (Eds.), Wahlen und Wähler. Analysen aus Anlaß der Bundestagswahl 1990. Westdeutscher Verlag, Opladen, pp. 214-263.

Glenn, N.D., 1974. Aging and conservatism. Annals of the American Academy of Political and Social Science 415, 176-186.

Glenn, N.D., Hefner, T., 1972. Further evidence on aging and party identification. Public Opinion Quarterly 36 (1), 31-47.

Gluchowski, P., 1983. Wahlerfahrung und Parteienidentifikation. Zur Einbindung von Wählern in das Parteiensystem der Bundesrepublik. In: Kaase, M., Klingemann, H.-D. (Eds.), Wahlen und politisches System. Westdeutscher Verlag, Opladen, pp. $442-477$.

Herbert, U., 2003. Drei politische Generationen im 20. Jahrhunderts. In: Reulecke, J. (Ed.), Generationalität und Lebensgeschichte im 20 Jahrhundert. R. Oldenbourg, Munich, pp. 95-114.
Himmelweit, H.T., Humphreys, P., Jaeger, M., 1985. How Voters Decide. Open University Press, Milton Keynes.

Inglehart, R., 1990. Culture Shift in Advanced Industrial Society. Princeton University Press, Princeton.

Mannheim, K., 1997 [1928]. The problem of generations. In: Hardy, M.A. (Ed.), Studying Aging and Social Change. Conceptual and Methodological Issues. Sage, Thousand Oaks/ London/New Delhi, pp. 22-65.

Markus, G.B., 1983. Dynamic modelling of cohort change: the case of political partisanship. American Journal of Political Science 27, 717-739.

Merkl, P.H., 1989. Introduction: forty years and seven generations In: Merkl, P.H. (Ed.), The Federal Republic of Germany at Forty. New York University Press, New York/London, pp. 1-18.

Miller, W.E., Shanks, J.M., 1996. The New American Voter. Harvard University Press, Cambridge, MA, USA/London, UK.

Niemi, R.G., Powell Jr., G.B., Stanley, H.W., Evans, C.L., 1985. Testing the converse partisanship model with new electorates. Comparative Political Studies 18, 300-322.

Norris, P., 1997. Electoral Change in Britain since 1945. Blackwell, Oxford/Cambridge, MA.

Peterson, P.G., 1999. Gray Dawn. How the Coming Age Wave will Transform America - and the World. Time Books, New York.

Rattinger, H., 1992. Demography and federal elections in Germany, 1953-1990 and beyond. Electoral Studies 11 (3), 223-247.

Russell, A.T., Johnston, R.J., Pattie, C.J., 1992. Thatcher's Children: exploring the links between age and political attitudes. Political Studies 40, 742-756.

Siaroff, A., 2000. Comparative European Party Systems. An Analysis of Parliamentary Elections since 1945. Garland, New York/London.

Spitzer, A.B., 1973. The historical problem of generations. The American Historical Review 78 (5), 1353-1385.

Stadie, R., 1986. Grunddaten zum politischen Verhalten älterer Menschen. Aus Politik und Zeitgeschichte B48, 21-34.

Tilley, J.R., 2002. Political generations and partisanship in the UK, 1965-1997. Journal of the Statistical Society (Series A) 165, $121-135$.

Tilley, J.R., 2003. Party identification in Britain: does length of time in the electorate affect strength of partisanship? British Journal of Political Science 33, 332-344.

Tilley, J.R., 2005. Libertarian-authoritarian value change in Britain, 1974-2001. Political Studies 53 (2), 442-453.

Vincent, J.A., Patterson, G., Wale, K., 2001. Politics and Old Age: Older Citizens and Political Processes in Britain. Ashgate, Aldershot. 